\title{
$\mathrm{BMJ}$
}

\section{Home based versus centre based cardiac rehabilitation: Cochrane systematic review and meta-analysis}

Hasnain M Dalal, honorary clinical lecturer, ${ }^{1}$ general practitioner, ${ }^{2}$ Anna Zawada, senior analyst, ${ }^{3}$ Kate Jolly, senior lecturer in public health and epidemiology, ${ }^{4}$ Tiffany Moxham, information specialist, ${ }^{5}$ Rod S Taylor, associate professor in health services research ${ }^{5}$

${ }^{1}$ Peninsula Medical School (Primary Care), Truro, Cornwall TR1 3HD

${ }^{2}$ Three Spires Medical Practice, Truro, Cornwall TR1 2LZ

${ }^{3}$ Agency for Health Technology Assessment, Warsaw, Poland

${ }^{4}$ University of Birmingham, Birmingham B15 2TT

${ }^{5}$ Peninsula Medical School (Primary Care), Exeter EX2 5DW Correspondence to: $\mathrm{H}$ M Dalal hmdalal@doctors.net.uk

Cite this as: BMJ 2010;340:b563 doi:10.1136/bmj.b5631

\section{ABSTRACT}

Objective To compare the effect of home based and supervised centre based cardiac rehabilitation on mortality and morbidity, health related quality of life, and modifiable cardiac risk factors in patients with coronary heart disease.

Design Systematic review.

Data sources Cochrane Central Register of Controlled Trials (CENTRAL) in the Cochrane Library, Medline, Embase, CINAHL, and PsycINFO, without language restriction, searched from 2001 to January 2008.

Review methods Reference lists checked and advice sought from authors. Included randomised controlled trials that compared centre based cardiac rehabilitation with home based programmes in adults with acute myocardial infarction, angina, or heart failure or who had undergone coronary revascularisation. Two reviewers independently assessed the eligibility of the identified trials and extracted data independently. Authors were contacted when possible to obtain missing information. Results 12 studies (1938 participants) were included. Most studies recruited patients with a low risk of further events after myocardial infarction or revascularisation. No difference was seen between home based and centre based cardiac rehabilitation in terms of mortality (relative risk $1.31,95 \%$ confidence interval 0.65 to 2.66 ), cardiac events, exercise capacity (standardised mean difference $-0.11,-0.35$ to 0.13 ), modifiable risk factors (weighted mean difference systolic blood pressure $(0.58 \mathrm{~mm} \mathrm{Hg}$, $-3.29 \mathrm{~mm} \mathrm{Hg}$ to $4.44 \mathrm{~mm} \mathrm{Hg}$ ), total cholesterol $(-0.13 \mathrm{mmol} / \mathrm{l},-0.31 \mathrm{mmol} / \mathrm{l}$ to $0.05 \mathrm{mmol} / \mathrm{l})$, low density lipoprotein cholesterol $(-0.15 \mathrm{mmol} / \mathrm{l}$, $-0.31 \mathrm{mmol} / \mathrm{l}$ to $0.01 \mathrm{mmol} / \mathrm{l}$ ), or relative risk for proportion of smokers at follow-up $(0.98,0.73$ to 1.31$)$ ), or health related quality of life, with the exception of high density lipoprotein cholesterol $(-0.06,-0.11$ to -0.02$)$ $\mathrm{mmol} / \mathrm{l})$. In the home based participants, there was evidence of superior adherence. No consistent difference was seen in the healthcare costs of the two forms of cardiac rehabilitation.

Conclusions Home and centre based forms of cardiac rehabilitation seem to be equally effective in improving clinical and health related quality of life outcomes in patients with a low risk of further events after myocardial infarction or revascularisation. This finding, together with the absence of evidence of differences in patients' adherence and healthcare costs between the two approaches, supports the further provision of evidence based, home based cardiac rehabilitation programmes such as the "Heart Manual." The choice of participating in a more traditional supervised centre based or evidence based home based programme should reflect the preference of the individual patient.

\section{INTRODUCTION}

Coronary heart disease is a major cause of mortality and morbidity. ${ }^{1-3}$ Although mortality from coronary heart disease has decreased in many developed countries in recent decades, morbidity is increasing as a result of improved diagnosis and more successful treatment of acute illness, which has resulted in an increase in the number of people who survive myocardial infarction. ${ }^{12}$ Cardiac rehabilitation is offered to people after cardiac events to aid recovery and prevent further cardiac illness. It has been shown to improve physical health and decrease subsequent morbidity and mortality in patients with coronary heart disease (myocardial infarction and after revascularisation). Two systematic reviews that included 48 randomised controlled trials showed a $20 \%$ reduction in all cause mortality and a $27 \%$ reduction in cardiac mortality at two to five years. ${ }^{45}$ Cardiac rehabilitation programmes typically achieve this through exercise, education, behaviour change, counselling, support, and strategies aimed at targeting traditional risk factors for cardiovascular disease. Cardiac rehabilitation is an essential part of the contemporary care of patients with heart disease and is considered a priority in countries with a high prevalence of coronary heart disease and heart failure. ${ }^{6-10}$

Although cardiac rehabilitation has been shown to have beneficial effects, participation remains suboptimal. The main reasons people give for not accepting the invitation to attend centre based cardiac rehabilitation classes-held for groups in hospitals, gyms, or community leisure centres - are problems with accessibility and parking at their local hospital, ${ }^{11-13}$ a dislike of groups, ${ }^{14}$ and work or domestic commitments. ${ }^{15-18}$ These problems can be overcome by home based 


\section{Table 1|Characteristics of excluded studies}

\begin{tabular}{ll} 
Citation & \multicolumn{1}{c}{ Reason for exclusion } \\
Ades et al, ${ }^{\text {w1 }} 2000$ & Not randomised controlled trial \\
\hline Tygssen et al, $^{\text {w2 } 2001}$ & Both trial arms received home based cardiac rehabilitation \\
\hline Senuzun et al, ${ }^{\text {w3 }} 2006$ & Trial arms involved home based cardiac rehabilitation and usual care \\
\hline Sinclair et al, ${ }^{\text {w4 }} 2005$ & Trial arms involved home based cardiac rehabilitation and usual care \\
\hline
\end{tabular}

programmes, which have been introduced in an attempt to widen access and participation. ${ }^{19}$

The one systematic review (of randomised controlled trials) that compared home based and centre based cardiac rehabilitation to date found no significant differences in outcomes, ${ }^{20}$ but there were only 750 participants in total and patients with heart failure were excluded. Two large randomised controlled trials that compared home based and centre based cardiac rehabilitation in the United Kingdom have recently been completed..$^{212}$ We determined the effectiveness of home based cardiac rehabilitation programmes compared with supervised centre based cardiac rehabilitation on mortality, morbidity, health related quality of life, and modifiable cardiac risk factors in patients with coronary heart disease.

\section{METHODS}

Criteria for considering studies for this review

Studies included-We included randomised controlled trials (individual or cluster level).

Types of participants - The study population included adults with myocardial infarction, angina, or heart failure and patients who had undergone revascularisation (coronary artery bypass grafting, percutaneous transluminal coronary angioplasty, or coronary artery stenting). All had taken part in or been invited to take part in cardiac rehabilitation. We excluded studies of participants with heart transplants, cardiac resynchronisation devices, or implantable defibrillators.

Types of interventions - Home based cardiac rehabilitation was defined as a structured programme, with clear objectives for the participants, including monitoring, follow-up, visits, letters, telephone calls from staff,

Titles identified from electronic bibliographies and screened for retrieval $(n=11561)$

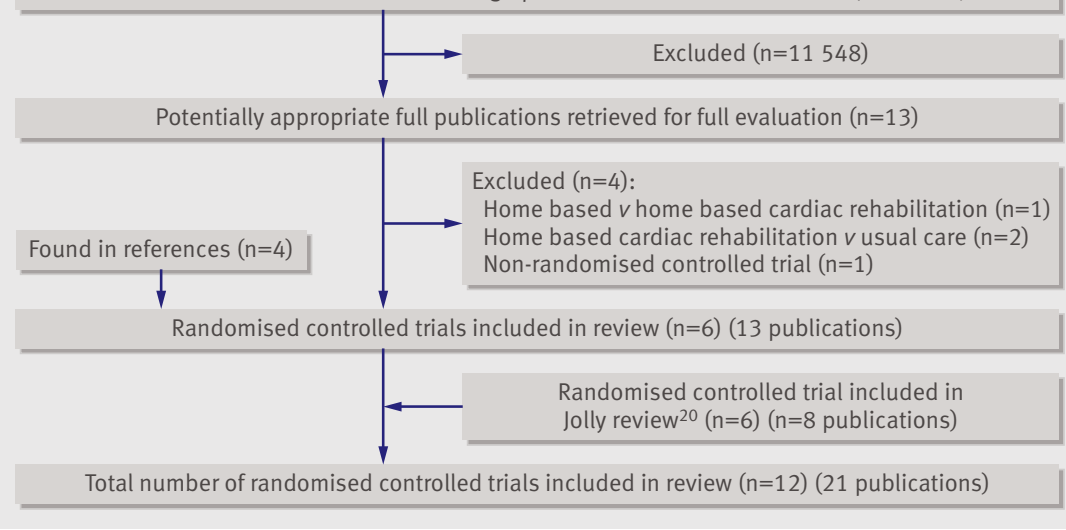

Fig 1 | Summary of study selection process or at least self monitoring diaries. Centre based cardiac rehabilitation was a supervised group based programme undertaken in a hospital or community setting such as a sports centre.

Types of outcome measures -Outcome measures included mortality (cardiac and overall), morbidity (reinfarction, revascularisation, and admission to hospital associated with cardiac disease), exercise capacity, modifiable coronary risk factors (smoking behaviour, blood lipid concentrations, and blood pressure), health related quality of life, adverse events (withdrawal from the exercise programme), health service use or costs, and cost effectiveness. During the review (and before any data analysis was undertaken), we agreed to include the outcome of adherence to the intervention.

\section{Search methods for identification of studies}

We identified randomised controlled trials from the previously published systematic review. ${ }^{20}$ We updated the list of studies by searching several clinical databases from 2001 to January 2008: the Cochrane Central Register of Controlled Trials (CENTRAL) in the Cochrane Library, Medline, Embase, CINAHL, and PsycINFO. We located additional studies in the databases of the NHS Centre for Reviews and Dissemination (the Health Technology Assessment (HTA) database and the Database of Abstracts of Reviews of Effects (DARE)). We searched conference proceedings on the ISI Web of Knowledge. We identified grey literature through a web search of major health technology appraisal agencies. We limited searches to randomised controlled trials, systematic reviews, and meta-analyses and imposed no language or other limitations.

Selection of studies - Two reviewers (RST and Philippa Davies) independently screened the titles and abstracts of studies identified by the search strategy and discarded clearly irrelevant studies. To be selected, abstracts needed to clearly identify the study design, define an appropriate population, and describe relevant components of the intervention, as defined above. The same two reviewers also independently assessed the full text reports of all potentially relevant trials and assessed them independently for eligibility on the basis of the defined inclusion criteria. They resolved any disagreement by discussion; if any uncertainty remained, they sought the opinion of two further reviewers (KJ and $\mathrm{AZ}$ ).

Data extraction and management -Data were extracted by a single reviewer (AZ) and checked by a second reviewer (RST). Standardised data extraction forms were used to extract relevant data regarding inclusion criteria (study design, participants, interventions, and outcomes), risk of bias (randomisation, blinding, attrition, and outcome reporting), and results. In cases for which insufficient details were reported, AZ contacted the authors for further information.

Assessment of risk of bias in included studies - The risk of bias in eligible trials was assessed by a single reviewer (AZ) and checked by a second reviewer (RST) in accordance with recent guidance. ${ }^{23}$ The risk of bias was 
Table 2|Summary of included studies

\begin{tabular}{|c|c|c|c|c|c|c|c|}
\hline Study & Methods & $\begin{array}{l}\text { No of } \\
\text { participants }\end{array}$ & Interventions & Outcomes & Follow-up & Subgroup analyses & $\begin{array}{l}\text { Country, } \\
\text { setting }\end{array}$ \\
\hline $\begin{array}{l}\text { Arthur et al, } \\
2002, \text { Smith et } \\
\text { al, }^{33} 2004\end{array}$ & $\begin{array}{l}\text { RCT parallel } \\
\text { group }\end{array}$ & 242 & $\begin{array}{l}\text { Home } v \text { centre } \\
\text { based }\end{array}$ & $\begin{array}{l}\text { Primary: exercise capacity (METs). Secondary: } \\
\text { HRQoL (SF-36), cardiac morbidity, mortality }\end{array}$ & $\begin{array}{l}6 \text { and } \\
18 \text { months after } \\
\text { randomisation }\end{array}$ & $\begin{array}{l}\text { No subgroups described or } \\
\text { reported }\end{array}$ & $\begin{array}{l}\text { Canada, single } \\
\text { centre }\end{array}$ \\
\hline Bell et al, ${ }^{30} 1998$ & $\begin{array}{l}\text { RCT parallel } \\
\text { group }\end{array}$ & 252 & $\begin{array}{l}\text { Home (Heart } \\
\text { Manual) } v \\
\text { centre based }\end{array}$ & $\begin{array}{l}\text { Primary: exercise capacity (METs). Secondary: } \\
\text { total cholesterol, systolic blood pressure, } \\
\text { HRQoL (NHP), smoking, mortality, } \\
\text { readmission rate, use of primary care services }\end{array}$ & $\begin{array}{l}16 \text { and } \\
48 \text { weeks after } \\
\text { randomisation } \\
\text { (20 and } \\
52 \text { weeks after } \\
\text { myocardial } \\
\text { infarction) }\end{array}$ & $\begin{array}{l}\text { No subgroups described or } \\
\text { reported }\end{array}$ & $\begin{array}{l}\text { UK, five district } \\
\text { hospitals }\end{array}$ \\
\hline
\end{tabular}

\begin{tabular}{|c|c|c|c|c|c|c|c|}
\hline $\begin{array}{l}\text { Carlson et al, } \\
2000\end{array}$ & $\begin{array}{l}\text { RCT parallel } \\
\text { group }\end{array}$ & 80 & $\begin{array}{l}\text { Home } v \text { centre } \\
\text { based }\end{array}$ & $\begin{array}{l}\text { Primary: peak functional capacity (METs), LDL } \\
\text { cholesterol. Secondary: total cholesterol, HDL } \\
\text { cholesterol, triglycerides, blood pressure, }\end{array}$ & $\begin{array}{l}6 \text { months after } \\
\text { randomisation }\end{array}$ & $\begin{array}{l}\text { No subgroups described or } \\
\text { reported }\end{array}$ & $\begin{array}{l}\text { US, single } \\
\text { hospital centre }\end{array}$ \\
\hline
\end{tabular}

cardiovascular medications, costs,

adherence (exercise sessions attended)

\begin{tabular}{|c|c|c|c|c|c|c|c|}
\hline $\begin{array}{l}\text { Dalal et al, } \\
\text { 2007, Taylor et }\end{array}$ & $\begin{array}{l}\text { RCT parallel } \\
\text { group }\end{array}$ & 104 & $\begin{array}{l}\text { Home (Heart } \\
\text { Manual) } v\end{array}$ & $\begin{array}{l}\text { Primary: quality of life (MacNew } \\
\text { questionnaire), total cholesterol. Secondary: }\end{array}$ & $\begin{array}{l}9 \text { months after } \\
\text { randomisation }\end{array}$ & $\begin{array}{l}\text { No subgroups described or } \\
\text { reported }\end{array}$ & UK, single centre \\
\hline
\end{tabular}

31 , Taylor et group questionnaire), total cholesterol. Secondary: randomisation reported

centre based exercise capacity (METs), self reported

smoking, cardiovascular morbidity, mortality, secondary prevention medication

\begin{tabular}{|c|c|c|c|c|c|c|c|}
\hline $\begin{array}{l}\text { Daskapan et } \\
\text { al, }^{34} 2005\end{array}$ & $\begin{array}{l}\text { RCT parallel } \\
\text { group }\end{array}$ & 29 & $\begin{array}{l}\text { Home } v \text { centre } \\
\text { based }\end{array}$ & $\begin{array}{l}\text { Exercise capacity }(\mathrm{ml} / \mathrm{kg} / \mathrm{min})^{\star} \text {, resting } \mathrm{BP}^{\star} \text {, } \\
\text { systolic and diastolic } \mathrm{BP}^{\star} \text {, adherence*, drop } \\
\text { outs }^{\star}\end{array}$ & $\begin{array}{l}12 \text { weeks after } \\
\text { randomisation }\end{array}$ & $\begin{array}{l}\text { No subgroups described or } \\
\text { reported }\end{array}$ & $\begin{array}{l}\text { Turkey, single } \\
\text { centre }\end{array}$ \\
\hline $\begin{array}{l}\text { Gordon et al, } \\
2002\end{array}$ & $\begin{array}{l}\text { RCT parallel } \\
\text { group }\end{array}$ & 155 & $\begin{array}{l}\text { Supervised } \\
\text { home } v \\
\text { community } \\
\text { home } v \text { centre }\end{array}$ & $\begin{array}{l}\text { Maximal oxygen uptake*, blood pressure*, } \\
\text { fasting serum lipids*, self reported smoking } \\
\text { status }^{\star} \text {, rehospitalisation*, adherence } \\
\text { (completion of appointments) }^{\star}\end{array}$ & $\begin{array}{l}12 \text { weeks after } \\
\text { randomisation }\end{array}$ & $\begin{array}{l}\text { Changes reported forall patients } \\
\text { and for patients with baseline } \\
\text { values defined as abnormal }\end{array}$ & US, single ce \\
\hline
\end{tabular}

Jollyetal, ${ }^{22} 2007$ RCT parallel $\quad 525 \quad$ Home (Heart Primary: serum cholesterol, total cholesterol, 6, 12, and group Manual) $v$

HDL cholesterol, blood pressure, exercise 24 months

centre based capacity (ISWT), smoking (validated by

cotinine). Secondary: quality of life (EQ-5D),

SF-12, health service use (hospital

readmissions, primary care visits,

medication), mortality, cardiovascular

events, costs

Yes ("interaction terms between UK, four hospital these factors (diagnosis (MI/ centres

revascularisation),

age, sex and ethnicity) and

rehabilitation setting were

included to investigate

possible differences in

treatment effect between

subgroups of patients")

\begin{tabular}{|c|c|c|c|c|c|c|c|}
\hline $\begin{array}{l}\text { Kassaian et al, }{ }^{25} \\
1998\end{array}$ & $\begin{array}{l}\text { RCT parallel } \\
\text { group }\end{array}$ & 125 & $\begin{array}{l}\text { Home } v \text { centre } \\
\text { based }\end{array}$ & $\begin{array}{l}\text { Systolic BP*, diastolic BP*, heart rate (all } \\
\text { resting and submaximal)*, functional } \\
\text { capacity }(\text { METs)*, BMI*, cholesterol (total, } \\
\text { LDL, HDL, triglycerides)* }^{\star}\end{array}$ & $\begin{array}{l}12 \text { weeks after } \\
\text { randomisation }\end{array}$ & $\begin{array}{l}\text { Comparison of functional } \\
\text { capacity, submaximal systolic } \\
\text { BP, diastolic BP and } \\
\text { heart rate in patients with left } \\
\text { ventricular dysfunction versus } \\
\text { good left ventricular function }\end{array}$ & $\begin{array}{l}\text { Iran, single } \\
\text { centre }\end{array}$ \\
\hline $\begin{array}{l}\text { Marchionni et } \\
\mathrm{al}^{24} 2003\end{array}$ & $\begin{array}{l}\text { RCT parallel } \\
\text { group }\end{array}$ & 180 & $\begin{array}{l}\text { Home } v \text { centre } \\
\text { based }\end{array}$ & $\begin{array}{l}\text { Primary: TWC. Secondary: HRQoL (SIP), } \\
\text { mortality, morbidity (cardiovascular events), } \\
\text { healthcare use (medical visits, } \\
\text { rehospitalisations), costs, adherence } \\
\text { (number of completed training sessions) }\end{array}$ & $\begin{array}{l}2,8 \text {, and } \\
14 \text { months after } \\
\text { randomisation }\end{array}$ & $\begin{array}{l}\text { Subgroup analysis by age } \\
\text { (years): middle aged ( } 45-65) \text {, } \\
\text { old (65-75), very old (>75) }\end{array}$ & $\begin{array}{l}\text { Italy, single } \\
\text { hospital centre }\end{array}$ \\
\hline $\begin{array}{l}\text { Miller et al, }{ }^{27} \\
1984, \text { DeBusk et } \\
\text { al, }^{28} 1985, \\
\text { Taylor et al, } \\
1986\end{array}$ & $\begin{array}{l}\text { RCT parallel } \\
\text { group }\end{array}$ & 127 & $\begin{array}{l}\text { Home } v \text { centre } \\
\text { based }\end{array}$ & $\begin{array}{l}\text { Exercise capacity }{ }^{\star} \text {, mortality*, cardiovascular } \\
\text { morbidity }\end{array}$ & $\begin{array}{l}23 \text { weeks after } \\
\text { randomisation }\end{array}$ & $\begin{array}{l}\text { Results reported according to } \\
\text { two subgroups reported (brief } v \\
\text { extended exercise training) }\end{array}$ & $\begin{array}{l}\text { US, single } \\
\text { hospital centre }\end{array}$ \\
\hline $\begin{array}{l}\text { Sparks et al, } \\
1993\end{array}$ & $\begin{array}{l}\text { RCT parallel } \\
\text { group }\end{array}$ & 20 & $\begin{array}{l}\text { Home } v \text { centre } \\
\text { based }\end{array}$ & $\begin{array}{l}\text { Exercise capacity (peak } \mathrm{VO}_{2} \text { max), adherence } \\
\text { (compliance with exercise), safety (drop out) }\end{array}$ & $\begin{array}{l}12 \text { weeks after } \\
\text { randomisation }\end{array}$ & $\begin{array}{l}\text { No subgroups described or } \\
\text { reported }\end{array}$ & $\begin{array}{l}\text { US, single } \\
\text { hospital centre }\end{array}$ \\
\hline Wu et al, ${ }^{35} 2008$ & $\begin{array}{l}\text { RCT parallel } \\
\text { group }\end{array}$ & 36 & $\begin{array}{l}\text { Home } v \text { centre } \\
\text { based }\end{array}$ & Exercise capacity (METs)* & $\begin{array}{l}12 \text { weeks after } \\
\text { randomisation }\end{array}$ & $\begin{array}{l}\text { No subgroups described or } \\
\text { reported }\end{array}$ & $\begin{array}{l}\text { Taiwan (China), } \\
\text { single centre }\end{array}$ \\
\hline
\end{tabular}

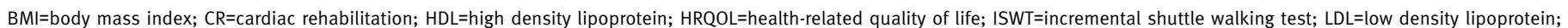

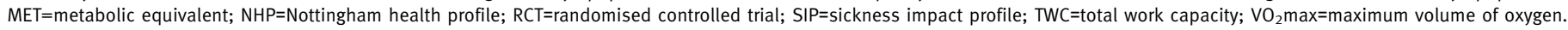

*Primary and secondary outcomes not distinguished.

assessed in terms of the quality of random sequence generation and allocation concealment, description of dropouts and withdrawals, blinding (participants, personnel, and outcome assessment), and selective outcome reporting. We determined whether groups were balanced at baseline and whether an intention to treat analysis was undertaken.

\section{Data synthesis}

We processed data in accordance with the Cochrane handbook. ${ }^{23}$ For dichotomous variables, we derived the relative risks and 95\% confidence intervals for each outcome. For continuous variables, we calculated the mean differences and 95\% confidence intervals for each outcome. When the results at follow-up and 


\section{Table 3| Summary of intervention details 2122 24-27 3032 34-37}

Arthur (2002) $)^{36}$

Exercise

\section{Other \\ Bell (1998) $)^{30}$ Heart Manual}

Exercise

Overall duration: 6 weeks. Frequency, duration, and intensity: NR

Other Four phone calls by facilitator, health education, and stress management

Carlson (2000) $)^{32}$

Exercise

Overall duration: 25 weeks, $2-5$ sessions/week, 30-40 min/session. Intensity: 60-85\% of aerobic capacity. Modality: aerobic exercise; for first 4 weeks, 3 hospital based exercise sessions/week with electrocardiographic monitoring and then progressive reduction in frequency of centre based sessions

Other Weekly educational and counselling meetings included sessions on exercise, diet, risk factors, drugs, and overcoming barriers to behaviour change. Based on Bandura's self efficacy theory

\section{Dalal (2007) $)^{21}$ Heart Manual}

Exercise

Overall duration: 6 weeks. Frequency, duration, and intensity: NR. Modality: walking. Home visit in first week after discharge by cardiac rehabilitation nurse followed by up to 4 telephone calls at 2, 3, 4, and 6 weeks

Other Stress management and education

Daskapan (2007) $)^{34}$

Exercise

Total duration: 12 weeks, 3 sessions/week, $45 \mathrm{~min} /$ session (including warm up, cool down, and recovery). Intensity: up to $60 \%$ of peak heart rate (12-16 on Borg rating of perceived exertion (RPE) scale). Modality: walking. Follow-up logs completed daily/returned biweekly. Weekly phone calls from staff to monitor adherence and progress. Monthly phone calls from patients for control purposes

Other NR

Gordon (2002) ${ }^{26}$

Exercise

Group I (supervised home based cardiac rehabilitation): total duration: 12 weeks. Intensity: individually prescribed (30-60 min of aerobic exercise at $60-85 \%$ of peak heart rate) gradually updated; appointments: two office visits and four phone calls. Group II (community home based cardiac rehabilitation): total duration: 12 weeks, individually prescribed (30-60 minutes of aerobic exercise at $60-85 \%$ of peak heart rate), gradually updated. Appointments: 12 onsite visits or telephone calls (patient choice)

Other Group I and group II: written materials, audiotapes, nutrition, weight and stress management, smoking cessation programme, individual management of risk factors for coronary artery disease

Jolly (2007) $)^{22}$ Heart Manual/Centre based cardiac rehabilitation (control)

Exercise Overall duration: six weeks of Heart Manual's programme and 12 weeks of nurse support. Frequency: up to daily. Duration and intensity: NR. Modality: walking

Other Education about risk factors, lifestyle changes, medications and stress management (relaxation tapes)

Kassaian (2000) $)^{25}$

Exercise Total duration: 12 weeks. Frequency and duration: NR. Intensity: "intensity based on exercise test results"

\section{Other} Patients taught to count their pulse rate

Marchionni (2003) ${ }^{24}$

Exercise

Overall duration: 8 weeks, 3 days/week, 1 h/session. Intensity: $70-85 \%$ of peak heart rate. Modality:

Overall duration: 8 weeks, 3 days/week, $1 \mathrm{~h} /$ session. Intensity: $70-8$
cycle ergometer. Physical therapist home visits every other week Other Monthly family oriented support groups

Miller (1984) $)^{27}$

Exercise

Overall duration: 8 weeks, 3 days/week, 1 h/session. Intensity: 70-85\% of peak heart rate. Modality: cycle ergometer. Physical therapist home visits every other week

Other Monthly family oriented support groups

Sparks (1993) ${ }^{37}$

Exercise

Overall duration: 12 weeks, 3 days/week, $1 \mathrm{~h} /$ session. Intensity $60-75 \%$ of peak heart rate. Modality: cycle ergometer. Trans-telephonic electrocardiographic monitoring

Other

$$
\text { Education materials on diet, medications, and risks and benefits of exercise }
$$

\section{Wu (2006) $)^{35}$}

Exercise

Total duration: 12 weeks, $\geq 3$ sessions/week, 30-60 min + $10 \mathrm{~min}$ warm up $+10 \mathrm{~min}$ cool-down/session. Intensity: $60-85 \%$ of maximum heart rate. Modality: fast walking or jogging. Exercise documented in record book. Prescription of exercise individually given and updated every two weeks by rehabilitation nurse

Other NR
Total duration: 6 months, 3 sessions/week, $40 \mathrm{~min} / \mathrm{session}$. Intensity: 60 $70 \%$ of maximum oxygen intake. Modality: cycle ergometer, treadmill, track walking and stair climbing. Supervised by exercise specialist and completed exercises log, reviewed every month

Dietary advice and psychological support

Overall duration and frequency: 12 weeks of 1 session/week or 4 weeks of 2 sessions/week, $\geq 20 \mathrm{~min} /$ session. Intensity: 3-4 on Borg rating of perceived exertion (RPE) scale

Education sessions: causes of coronary heart disease, medication, risk factor modification, stress management, exercise

Overall duration: 25 weeks, $2-3$ sessions/week, $30-45 \mathrm{~min} /$ session Intensity: $60-85 \%$ of aerobic capacity. Modality: aerobic exercise

Three sessions of education and counselling that included sessions on exercise, diet, risk factors, and drugs

Overall duration: 8-10 weeks, $1-5$ sessions/week. Duration and modality: NR. Supervised and group based

Input from dietician, psychologist, occupational therapist and pharmacist

Total duration: 12 weeks, 3 sessions/week, $45 \mathrm{~min} /$ session (including warm up, cool down, and recovery). Intensity: $60 \%$ of peak heart rate. Modality: walking on a treadmill. Supervised

NR

Total duration: 12 weeks, 3/sessions/week (total of 36 sessions and appointments). Intensity: individually prescribed (30-60 minutes of aerobic exercise at $60-85 \%$ of peak heart rate). Continuous electrocardiographic telemetry during exercise

Written materials, audiotapes, education on risk factors for coronary arter disease, and lifestyle modification

Total duration: 6-12 weeks, 1-2 sessions/week, 25-30 min/session. Intensity: $65-75 \%$ of maximum heart rate. Modality: circuit training, cycle ergometer

Education and stress management (relaxation)

Total duration: 12 weeks, 3 sessions/week, 20-30 min, 10 min warm up, and $10 \mathrm{~min}$ cool-down/session. Intensity: $60-85 \%$ (NR if relative to maximum heart rate or maximum oxygen intake). Modality: treadmill

Overall duration: programme of 12 weeks, 3 days/week. Duration: NR. Intensity $70-85 \%$ of peak heart rate. Modality: cycle ergometer. Transtelephonic electrocardiographic monitoring during exercise Risk factor management counselling; support group meetings

Overall duration: 8 weeks (brief) or 23 weeks (extended), 5 sessions/week, $60 \mathrm{~min} /$ session. Intensity: $70-85 \%$ of maximum heart rate. Modality: walking/jogging. Group based and supervised No education or psychological intervention reported

Overall duration: 12 weeks, 3 days/week, 1 h/session. Intensity $60-75 \%$ of peak heart rate. Modality: cycle ergometer. No trans-telephonic electrocardiographic monitoring

Education materials on diet, medications, and risks and benefits of the exercise

Total duration: 12 weeks, 3 sessions/week (total 36 sessions), 30-60 min +10 minute warm up + 10 minute cool-down/session. Intensity: $60-85 \%$ of maximum heart rate. Modality: cycle ergometer, treadmill. Exercise supervised by cardiopulmonary physical therapist 
Table 4 |Summary of risk of bias assessment

\begin{tabular}{|c|c|c|c|c|c|}
\hline Study & $\begin{array}{l}\text { Adequate sequence } \\
\text { generation }\end{array}$ & $\begin{array}{l}\text { Allocation } \\
\text { concealment }\end{array}$ & $\begin{array}{l}\text { Outcome } \\
\text { blinding }\end{array}$ & $\begin{array}{l}\text { Incomplete outcome } \\
\text { data addressed }\end{array}$ & $\begin{array}{l}\text { Intention to treat } \\
\text { analysis }\end{array}$ \\
\hline Arthur $(2002)^{36}$ & Unclear & Yes & Yes & $\begin{array}{l}\text { Yes (dropout rate: } 8 \% \text { and } 10 \% \text { at } 6 \\
\text { and } 18 \text { months, respectively) }\end{array}$ & Yes \\
\hline Bell $(1998)^{30}$ & Unclear & Yes & Yes & Unclear & No \\
\hline Carlson $(2000)^{32}$ & Unclear & Unclear & Unclear & No & Yes \\
\hline Dalal $(2007)^{21}$ & Yes & Yes & Yes & Yes & Yes \\
\hline Daskapan $(2007)^{34}$ & Unclear & Unclear & Unclear & Yes & No \\
\hline Gordon $(2002)^{26}$ & Unclear & Unclear & Unclear & Yes & Unclear \\
\hline Jolly $(2007)^{22}$ & Yes & Yes & Yes & Yes & Yes \\
\hline Kassaian $(2000)^{25}$ & Unclear & Unclear & Unclear & Unclear & Unclear \\
\hline Marchionni (2003) ${ }^{24}$ & Unclear & Unclear & Yes & Yes & Yes \\
\hline Miller $(1984)^{27}$ & Unclear & Unclear & Unclear & Yes & Yes \\
\hline Sparks $(1993)^{37}$ & Unclear & Unclear & Unclear & Yes & Yes \\
\hline Wu $(2006)^{35}$ & Unclear & Unclear & Yes & Unclear & Unclear \\
\hline
\end{tabular}

differences between groups for each of the individual trials were not reported in the original publications, we calculated $\mathrm{P}$ values for the differences. ${ }^{23}$

We explored heterogeneity among the included studies qualitatively (by comparing the characteristics of included studies) and quantitatively (using the $\chi^{2}$ test of heterogeneity and $\mathrm{I}^{2}$ statistic). When appropriate, we combined the results from included studies for each outcome to give an overall estimate of the treatment effect. We used a fixed effect model for meta-analysis, except where we identified statistical heterogeneity, when we used a random effects model instead. In the protocol for this review, we intended to use metaregression to explore heterogeneity and examine potential treatment effect modifiers. Given the small number of included trials, however, such analyses were deemed inappropriately underpowered. Instead, we undertook specific stratified meta-analyses to examine the sensitivity of the findings of the review to key potential causes of heterogeneity. Continuous outcomes were pooled as a weighted mean difference except for the exercise capacity measures, which we expressed as a standardised mean difference because of the variety of measures. In the study that reported continuous outcome findings by three age subcategories, we pooled results to produce a single omnibus score for each group. ${ }^{24}$

We used sensitivity analysis to examine two areas of uncertainty. Firstly, for exercise capacity, in addition to pooling all trials with standardised mean difference, we pooled most trials that reported outcomes as metabolic equivalents using weighted mean difference. Secondly, the lack of detailed reporting meant that there was some doubt about whether or not the study by Kassaian et al was a true comparison between home based and hospital based cardiac rehabilitation or was, instead, a comparison of hospital based cardiac rehabilitation and usual care. ${ }^{25}$ We undertook all meta-analyses with and without this trial.

Gordon et al compared two home based exercise programmes with a centre based cardiac rehabilitation programme $^{26}$ and Miller et al reported results in subgroups by the duration of intervention. ${ }^{27-29}$ For these two studies, we included outcome results in the meta-analysis separately for the two home based groups and for the short and long duration exercise groups, respectively.

\section{RESULTS}

Description of studies

Search results - The systematic review by Jolly et al identified six trials (eight papers), ${ }^{20}$ all of which met the inclusion criteria of this review. Our updated electronic searches yielded a total of 11561 titles. After we reviewed the titles and abstracts, we retrieved an additional 13 full papers for possible inclusion and identified a further four from the reference lists of eligible publications. We excluded four papers (see bmj.com). In total, we included 21 papers that reported on 12 studies. Figure 1 summarises the study selection process, and table 1 gives details of the excluded studies and reasons for their exclusion.

Included studies-Three studies were based in the UK, ${ }^{21223031}$ four in the United States. ${ }^{26-2932}$ and one each in Canada, ${ }^{3334}$ Turkey, ${ }^{35}$ Italy, ${ }^{24}$ Iran, ${ }^{4}$ and China $^{36}$ (table 2). Most studies reported outcomes up to 12 months after randomisation; only three reported longer follow-up of 24 months, ${ }^{22} 14$ months, ${ }^{24}$ and 18 months. ${ }^{334}$ Eight studies compared comprehensive programmes (that is, exercise plus education or psychological management, or both), while the remainder reported only on an exercise inter vention. $^{2527-2935-37}$ The cardiac rehabilitation programmes differed considerably in duration (range 1. 5-6 months), frequency (1-5 sessions/week), and session length (20-60 minutes/session). Most programmes involved the prescription of individually tailored exercise programmes, which makes it difficult to precisely quantify the amount of exercise undertaken. Several home based programmes included a short initial period of centre based intervention. ${ }^{263234}$ Centre based programmes typically involved supervised exercise involving cycles and treadmills, while virtually all home based programmes were based on walking, with 
Table 5 |Summary of effects of home based versus centre based cardiac rehabilitation ${ }^{2122}$ 24-36

\begin{tabular}{|c|c|c|c|c|c|c|c|c|}
\hline \multirow[b]{2}{*}{ Outcome or subgroup } & \multirow{2}{*}{$\begin{array}{c}\text { No of } \\
\text { studies }\end{array}$} & \multirow{2}{*}{$\begin{array}{c}\text { No of } \\
\text { participants }\end{array}$} & \multirow[b]{2}{*}{ Summary estimate and model } & \multirow{2}{*}{$\begin{array}{l}\text { Effect estimate } \\
\qquad(95 \% \mathrm{Cl})\end{array}$} & \multicolumn{4}{|c|}{ Heterogeneity } \\
\hline & & & & & $\chi^{2}$ & df & $P$ value & $12(\%)$ \\
\hline \multicolumn{9}{|l|}{ Exercise capacity: } \\
\hline At 3-12 month follow-up & 14 & 1938 & Standard mean difference, random effects model & $-0.11(-0.35$ to 0.13$)$ & 60.91 & 13 & $<0.001$ & 79 \\
\hline At $12-24$ month follow-up & 4 & 1074 & Standard mean difference, fixed effects model & $0.11(-0.01$ to 0.23$)$ & 0.87 & 3 & 0.62 & 0 \\
\hline \multicolumn{9}{|c|}{ Blood pressure $(\mathrm{mm} \mathrm{Hg})$ at 3-12 month follow-up: } \\
\hline Systolic & 9 & 1053 & Mean difference, random effects model & $-0.51(-4.63$ to 3.61$)$ & 23.01 & 7 & 0.002 & 70 \\
\hline Diastolic & 7 & 927 & Mean difference, random effects model & $1.85(0.74$ to 2.96$)$ & 7.97 & 6 & 0.24 & 25 \\
\hline \multicolumn{9}{|c|}{ Cholesterol $(\mathrm{mmol} / \mathrm{l})$ at 3-12 month follow-up: } \\
\hline Total & 7 & 1019 & Mean difference, random effects model & $0.13(-0.05$ to 0.31$)$ & 13.33 & 6 & 0.04 & 55 \\
\hline High density lipoprotein & 5 & 793 & Mean difference, fixed effects model & $-0.06(-0.11$ to -0.02$)$ & 4.44 & 3 & 0.22 & 32 \\
\hline Low density lipoprotein & 4 & 324 & Mean difference, fixed effects model & $0.15(-0.01$ to 0.31$)$ & 6.53 & 4 & 0.16 & 39 \\
\hline Triglycerides & 4 & 328 & Mean difference, random effects model & $0.15(-0.11$ to 0.41$)$ & 7.58 & 3 & 0.06 & 60 \\
\hline Smoking & 5 & 922 & Relative risk, fixed effects model & $1.02(0.76$ to 1.37$)$ & 4.48 & 4 & 0.34 & 11 \\
\hline Completers & 10 & 1714 & Risk ratio, fixed effects model & $1.00(0.97$ to 1.04$)$ & 11.4 & 10 & 0.32 & 13 \\
\hline Mortality & 4 & 909 & Relative risk, fixed effects model & $1.31(0.65$ to 2.66$)$ & 1.00 & 3 & 0.80 & 0 \\
\hline
\end{tabular}

some level of intermittent telephone support from a nurse or exercise specialist (table 3). Most studies recruited patients at low risk of another event after acute myocardial infarction or revascularisation, excluding those with severe arrhythmias, ischaemia, or heart failure. Two studies included patients with New York Heart Association class 2 or 3 heart failure. ${ }^{2535}$

Risk of bias in included studies

Several studies failed to give enough detail for us to assess the potential risk of bias. Details of the generation and concealment of the random allocation sequence was particularly poorly reported. Only one study presented objective evidence of an imbalance in baseline characteristics. ${ }^{334}$ Only six studies stated that they took measures to blind those involved in assessments. Losses to follow-up varied considerably and were often asymmetric across the home based and centre based cardiac rehabilitation groups. Although the type of analysis was often not stated, all studies seemed to undertake an intention to treat analysis, in that groups were analysed according to the initial random allocation. Only a few trials examined the impact of losses to follow-up or drop out. As discussed above, the rehabilitation intervention was usually tailored to the individual patient, so it is difficult to quantify the precise level of intervention; however, the intensity of the rehabilitation programme seemed to differ substantially between the home based and centre based arms. Table 4 gives a summary of the assessment of risk of bias for each included study.

\section{Effects of interventions on exercise capacity}

All 12 included trials reported exercise capacity in the short term (3-12 months of follow-up), while

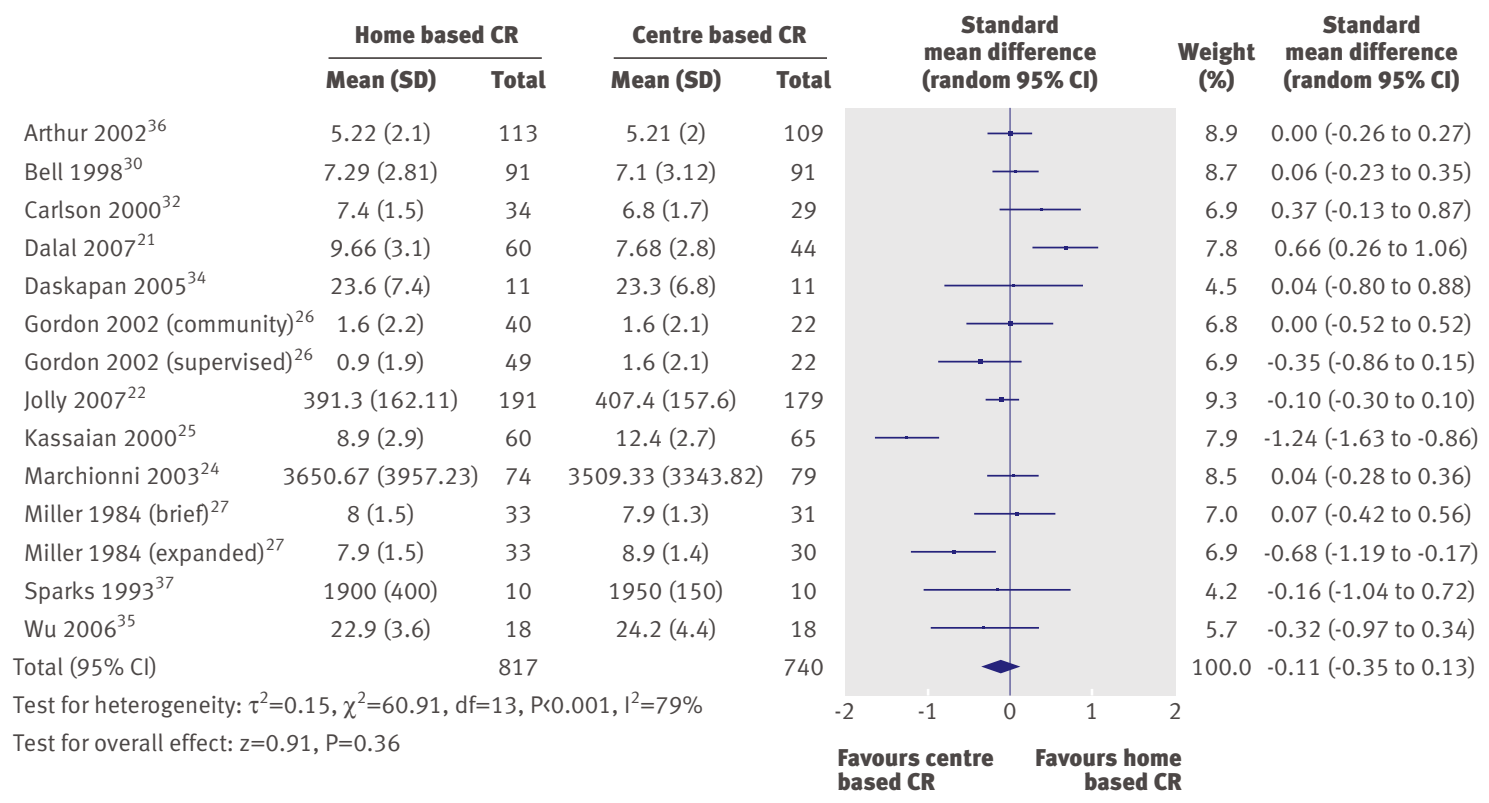

$\overline{\text { Fig } 2}$ 2 Exercise capacity with home based and centre based cardiac rehabilitation (CR) at 3-12 months of follow-up 


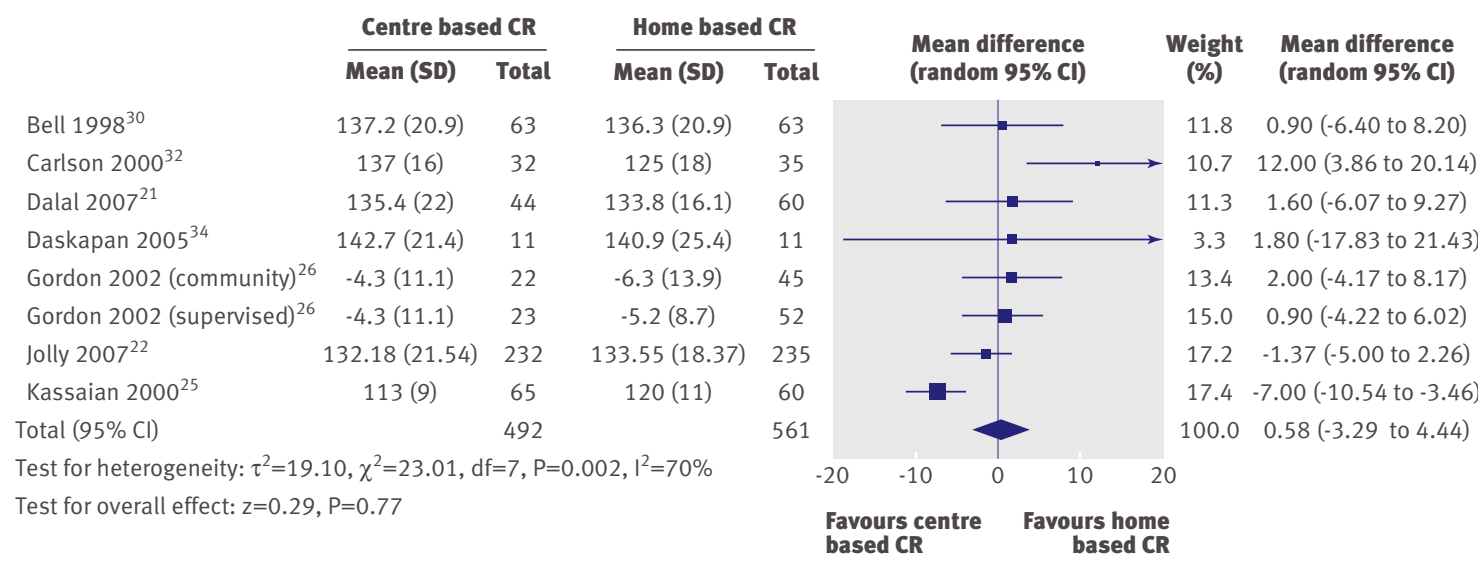

Fig 3 | Systolic blood pressure with home based and centre based cardiac rehabilitation at 3-12 months of follow-up

three 22243344 presented longer term data. Nine studies reported exercise capacity as the maximum oxygen intake, ${ }^{37}$ Jolly et al reported incremental shuttle walking distance, ${ }^{22}$ Marchionni et al reported total cycle work capacity, ${ }^{24}$ and Gordon et al reported data on change from baseline only as metabolic equivalents. ${ }^{26}$

The pooled analysis across all studies showed no evidence of a significant difference in short term exercise capacity between the home based and centre based cardiac rehabilitation groups (table 5 and fig 2). Evidence showed substantial heterogeneity, but the findings were the same when we limited pooling to the eight trials that reported maximum oxygen intake (random effects weighted mean difference $-0.30(-1.22$ to $0.63)$, heterogeneity $\chi^{2}=62.12, \quad \mathrm{df}=13, \quad \mathrm{P}<0.001$, $\mathrm{I}^{2}=79 \%$ ). In a pooled analysis of the three studies that reported longer term data (14-24 months), ${ }^{22} 243334$ some evidence indicated that exercise capacity with home based rehabilitation was better (albeit not significantly) than with centre based rehabilitation (fixed effects standardised mean difference $0.11(-0.01$ to $0.23)$, heterogeneity $\left.\chi^{2}=0.97, \mathrm{df}=2, \mathrm{P}=0.62, \mathrm{I}^{2}=0 \%\right)$.

\section{Modifiable risk factors}

Blood pressure - Seven of the included trials reported on systolic and diastolic blood pressure ${ }^{212225263235}$ or systolic blood pressure alone. ${ }^{30}$ Outcome at follow-up was reported in all but one study, ${ }^{26}$ which instead reported change from baseline. We obtained unpublished follow-up data for the study by Dalal et al from the authors. ${ }^{21}$ Although no difference in pooled systolic blood pressure was found between the groups at follow-up of 3-12 months (fig 3), diastolic blood pressure at follow-up was slightly higher for home based than for centre based cardiac rehabilitation (fixed effects weighted mean difference 1.85 (0.74 to 2.96) $\mathrm{mm} \mathrm{Hg}$, heterogeneity $\chi^{2}=7.97, \mathrm{df}=6, \mathrm{P}=0.24, \mathrm{I}^{2}=25 \%$ ) (fig 4$)$. At 24 months' follow-up, Jolly et al reported no significant difference in systolic blood pressure between the home and centre based cardiac rehabilitation groups. ${ }^{22}$

Blood lipids - Six of the included trials reported data on blood lipids. ${ }^{212225263032}$ All six reported total cholesterol values, four reported high density lipoprotein cholesterol concentrations, ${ }^{2252632}$ and three reported low density lipoprotein cholesterol and triglyceride concentrations. ${ }^{252632}$ High levels of heterogeneity were seen with total cholesterol. Figures 5-8 summarise the results. The pooled analysis of data at 3-12 months of follow-up found no evidence of differences in total cholesterol, low density lipoprotein cholesterol, or triglycerides at follow-up but concentrations of high density lipoprotein cholesterol were higher with centre based compared with home based rehabilitation (fixed effects weighted mean difference $-0.06(-0.11$ to -0.02$) \mathrm{mmol} /$

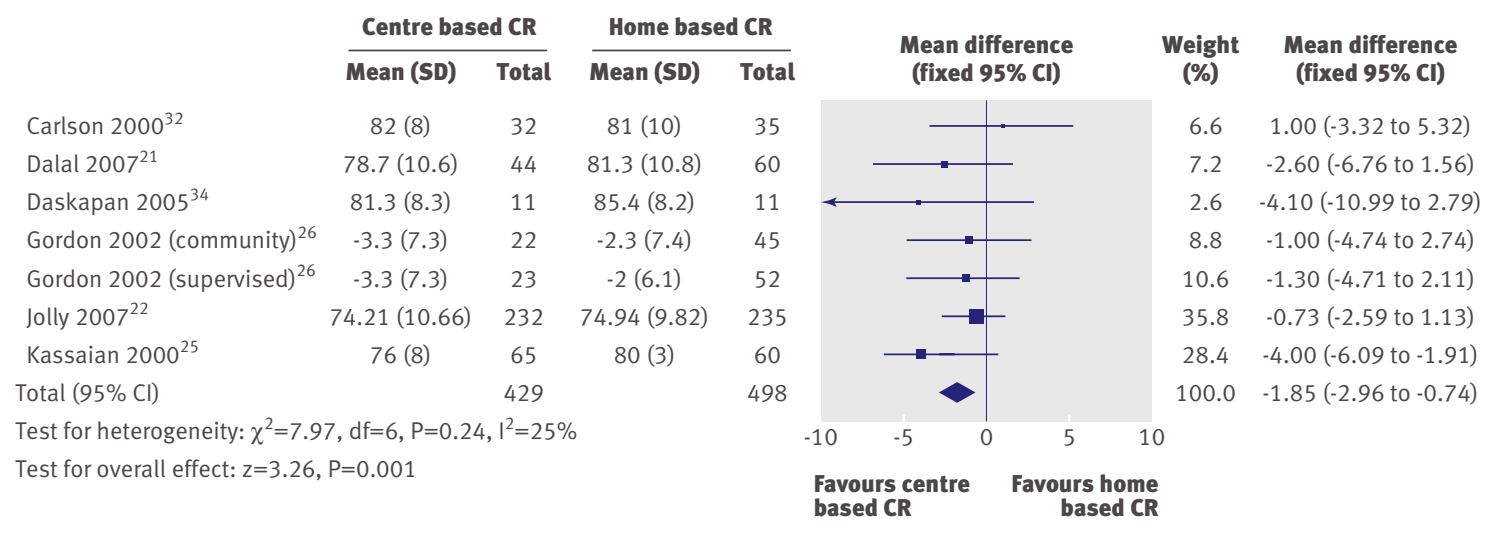

Fig 4 | Diastolic blood pressure with home based and centre based cardiac rehabilitation (CR) at 3-12 months of follow-up 


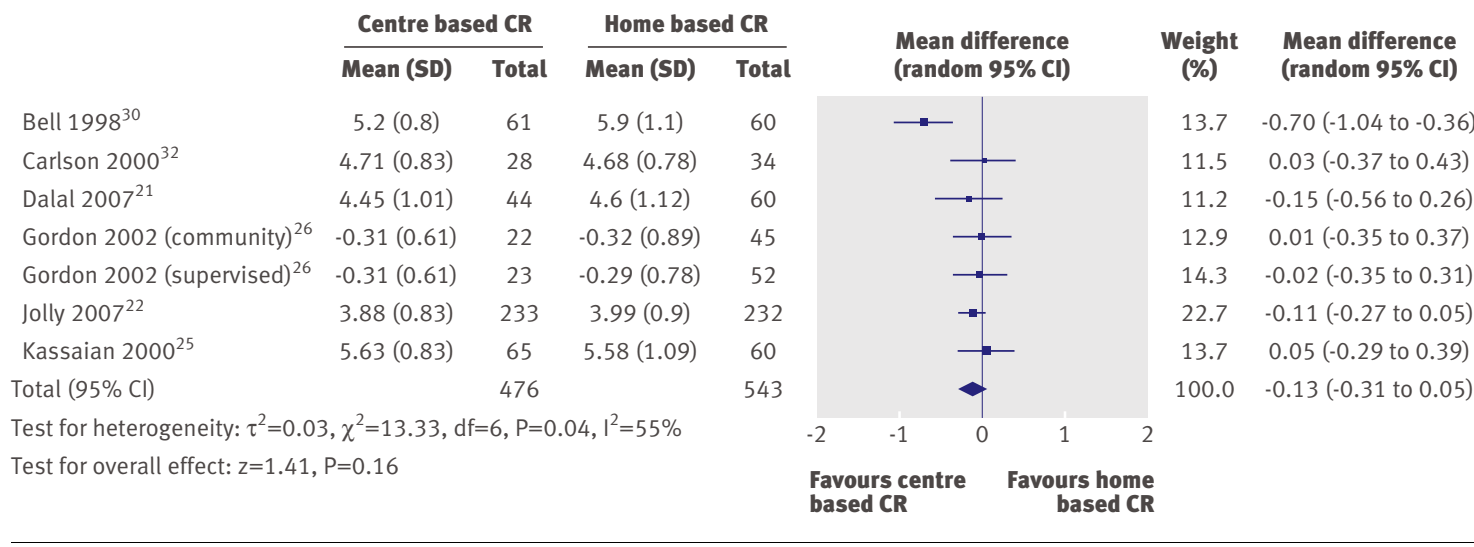

Fig 5 | Total cholesterol (mmol/l) with home based and centre based cardiac rehabilitation at 3-12 months of follow-up

1 , heterogeneity $\left.\chi^{2}=6.53, \mathrm{df}=4, \mathrm{P}=0.16, \mathrm{I}^{2}=39 \%\right)$. Jolly et al reported no significant difference between home based and centre based cardiac rehabilitation in terms of total cholesterol or high density lipoprotein cholesterol at follow-up of 24 months. ${ }^{22}$

Smoking behaviour-Four studies reported on patients' self reported smoking behaviour at 3-12 months of follow-up. ${ }^{2122263032}$ No evidence indicated a difference in the proportion of smokers at follow-up between centre based and home based cardiac rehabilitation (table 5 and fig 9). Jolly et al reported no difference in smoking between home based and centre based arms at 24 months. ${ }^{22}$

Health related quality of life - Five of the trials reported validated measures of health related quality of life (table 6): five generic instruments (EQ-5D, Nottingham health profile, SF-36, SF-12, and sickness impact profile) and one disease specific instrument (MacNew). The wide variation in health related quality of life measures meant that pooling across studies was inappropriate. Overall, there were no significant differences in overall health related quality of life outcomes or domain scores at follow-up between home based and centre based cardiac rehabilitation. The two exceptions were a higher score for the sleep domain of the Nottingham health profile with hospital based cardiac rehabilitation than home based rehabilitation in the study by Bell et $\mathrm{al}^{30}$ and a higher score for the physical component of the SF-36 with home based than centre based cardiac rehabilitation at six months in the study by Arthur et al. ${ }^{33} 34$

\section{Clinical events}

Mortality-Five trials reported all cause mortality up to one year of follow-up. ${ }^{212227-3032}$ Miller et al reported no deaths over the period of the study. ${ }^{27}$ A pooled analysis of the remaining studies found no evidence of a significant difference in mortality at 3-12 months' follow-up between home based and centre based rehabilitation (fig 10). Jolly et al reported no difference in mortality between the groups at 24 months of follow up. ${ }^{22}$

Cardiac events -Only two studies reported cardiac events during the exercise programme: Dalal et $\mathrm{al}^{21}$ (coronary artery bypass graft and percutaneous transluminal coronary angiography) and Jolly ${ }^{22}$ (myocardial infarction and revascularisation at 12 months and 24 months of follow-up). No significant difference was found between the home based and centre based programmes.

\section{Withdrawals and adherence}

Dropout rates from the intervention were inconsistently reported, and the reasons were often unclear. Using the number of completers - that is, the number of patients with outcome data at follow-up - we found no difference between home based and centre based programmes (fixed effect relative risk 1.00 (0.97 to $1.04)$, heterogeneity $\chi^{2}=11.44, \mathrm{df}=10, \mathrm{P}=0.32, \mathrm{I}^{2}=13 \%$ )

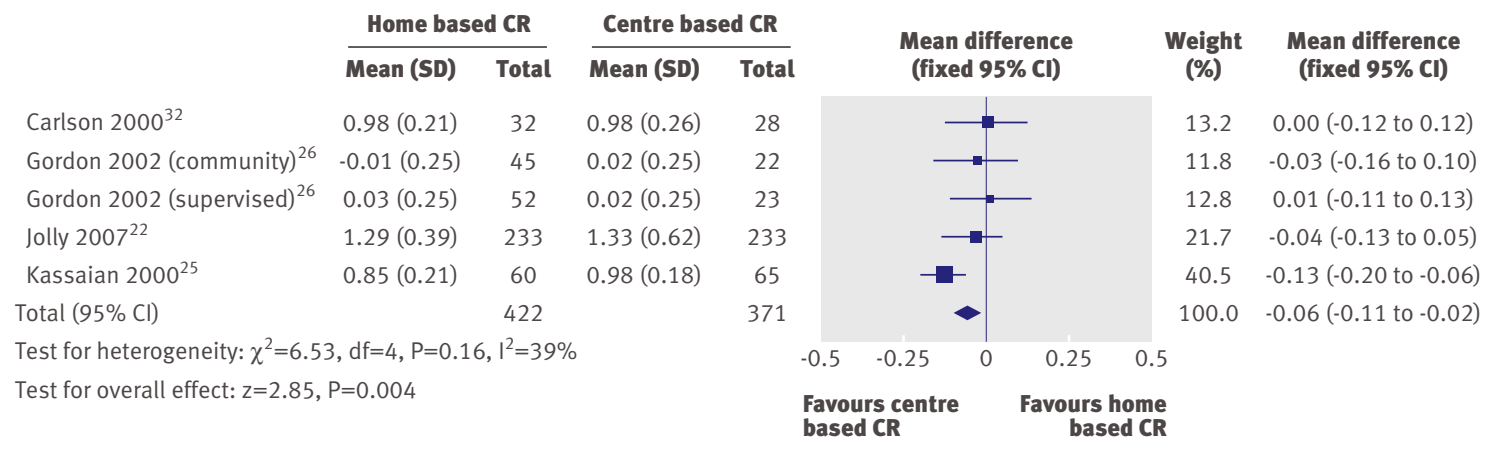

Fig 6 | High density lipoprotein cholesterol (mmol/l) with home based and centre based cardiac rehabilitation at 3-12 months of follow-up 


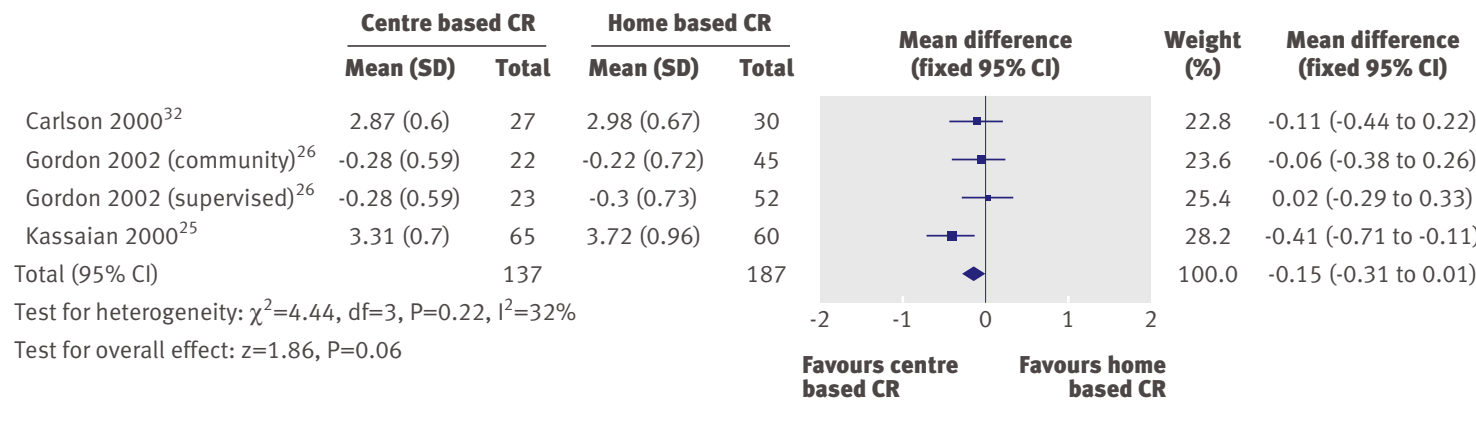

Fig 7| Low density lipoprotein cholesterol (mmol/l) with home based and centre based cardiac rehabilitation at 3-12 months of follow-up

(fig 11). Nine of the trials reported adherence to the cardiac rehabilitation intervention over the duration of the study. Substantial variations in the way in which adherence was defined and measured were seen, and some studies reported more than one measure of adherence. Pooling across studies was therefore deemed inappropriate. Table 7 summarises the findings related to adherence for each individual trial. Two studies found no evidence of a significant difference in the level of adherence between the groups, while there was evidence of a trend towards higher adherence in the studies of Carlson et al and Jolly et al. ${ }^{22} 32$ Adherence was significantly superior $(\mathrm{P} \leq 0.05)$ with home based cardiac rehabilitation in the studies by Arthur et al and Marchionni et al. ${ }^{243344}$ No study reported significantly higher adherence with centre based than home based rehabilitation. Figure 11 shows a metaanalysis based on the number of participants with outcome data at follow-up, who we have deemed to be completers.

\section{Costs and healthcare use}

Four studies reported costs (table 8). Differences in currencies and the timing of studies means that it was not possible to compare the costs directly across studies. In three of the four studies ${ }^{21243132}$ the healthcare costs associated with cardiac rehabilitation were lower for the home based than the centre based programmes, although in only one was the cost significantly lower. ${ }^{2132}$ Jolly et al found that home cardiac rehabilitation was more expensive than centre based rehabilitation, although the costs of the two would be the same if patients' costs were included. ${ }^{22}$
Six studies reported different aspects of consumption of healthcare resources, including readmissions to hospital, primary care consultations, and use of secondary care medication (table 9). No significant between group differences were seen.

\section{Sensitivity analyses}

When we removed data from the study by Kassaian et $\mathrm{al}^{25}$ from the analyses, the only difference in findings was that the difference between groups in diastolic blood pressure was not significant. Conclusions were also the same when we limited analyses to those studies with comprehensive programmes, except that there was no longer evidence of differences in diastolic blood pressure (fixed effects weighted mean difference $0.89(-0.45$ to 2.23$) \mathrm{mm} \mathrm{Hg}$, heterogeneity $\chi^{2}=1.55$, $\left.\mathrm{df}=4, \mathrm{P}=0.82, \mathrm{I}^{2}=0 \%\right)$ and high density lipoprotein cholesterol $(-0.02(-0.08$ to 0.04$) \mathrm{mmol} / \mathrm{l}$, heterogeneity $\left.\chi^{2}=0.53, \mathrm{df}=3, \mathrm{P}=0.91, \mathrm{I}^{2}=0 \%\right)$.

\section{DISCUSSION}

In this systematic review we assessed the evidence from randomised controlled trials that compared outcomes with home based and centre based cardiac rehabilitation. We found no evidence of a difference in outcomes in patients with stable coronary heart disease who received home based or centre based cardiac rehabilitation in the short term (3-12 months) or longer term (up to 24 months). Outcomes considered included exercise capacity, modifiable risk factors (blood pressure, concentrations of lipids in blood, and smoking), health related quality of life, and cardiac events (including mortality, revascularisation, and

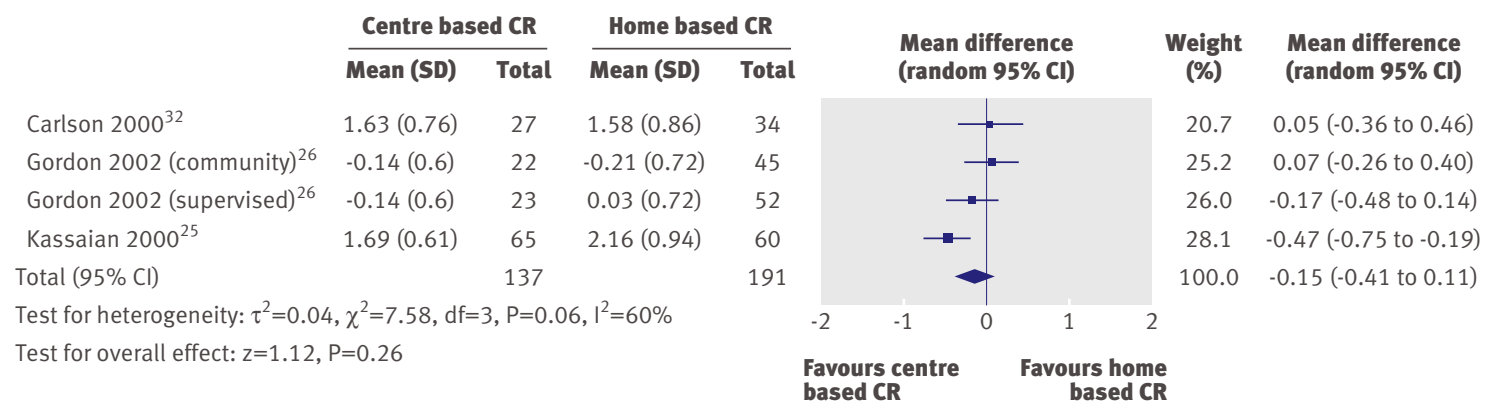

Fig 8 | Triglycerides (mmol/l) with home based and centre based cardiac rehabilitation at 3-12 months of follow-up 
Table 6 | Summary of health related quality of life (HRQoL) scores at follow-up for home based and centre based rehabilitation

\begin{tabular}{|c|c|c|c|c|}
\hline \multirow[b]{2}{*}{ Measure of HRQoL } & \multicolumn{2}{|c|}{$\begin{array}{l}\text { Mean (SD) outcome } \\
\text { values at follow-up }\end{array}$} & \multirow[b]{2}{*}{$P$ value } & \multirow{2}{*}{$\begin{array}{c}\text { Difference } \\
\text { between } \\
\text { groups* }\end{array}$} \\
\hline & Home & Centre & & \\
\hline \multicolumn{5}{|c|}{ Bell et al, ${ }^{30} 1998$ at 10.5 month follow-up } \\
\hline \multicolumn{5}{|l|}{ Nottingham health profile: } \\
\hline Energy & $18.6(28.4)$ & $17.3(30.7)$ & $0.78 \dagger$ & Home $=$ centre \\
\hline Pain & $6.6(15.3)$ & $7.4(15.5)$ & $0.74 \dagger$ & Home $=$ centre \\
\hline Emotional reactions & $6.6(15.3)$ & $7.4(15.5)$ & $0.74 \dagger$ & Home $=$ centre \\
\hline Sleep & $6.6(15.3)$ & $16.9(22.8)$ & $0.0007 \dagger$ & Home $<$ centre \\
\hline Social isolation & $3.7(13.6)$ & $6.7(15.0)$ & $0.18 \dagger$ & Home $=$ centre \\
\hline Physical mobility & $6.9(13.5)$ & $9.1(15.9)$ & $0.33 \dagger$ & Home $=$ centre \\
\hline \multicolumn{5}{|c|}{ Arthur et al, ${ }^{36} 2002$, Smith et al, ${ }^{33} 2004$} \\
\hline \multicolumn{5}{|l|}{ At 6 month follow-up: } \\
\hline SF-36 & $51.2(6.4)$ & $48.6(7.1)$ & $0.003 \dagger$ & Home $>$ centre \\
\hline \multicolumn{5}{|l|}{ PCS } \\
\hline$\overline{M C S}$ & $53.5(6.4)$ & $52.0(8.1)$ & $0.13 \dagger$ & Home $=$ centre \\
\hline \multicolumn{5}{|l|}{ At 18 month follow-up: } \\
\hline \multicolumn{5}{|l|}{ SF-36 } \\
\hline PCS & $48.3(11.7)$ & $47.6(11.7)$ & $0.67 \dagger$ & Home $=$ centre \\
\hline$\overline{M C S}$ & $53.0(10.9)$ & $50.2(10.9)$ & $0.07 \dagger$ & Home $=$ centre \\
\hline \multicolumn{5}{|l|}{ Marchionni et al, ${ }^{31} 2003$} \\
\hline SIP at 2 month follow-up & $2.83(14.5)$ & $4.71(11.1)$ & $0.09 \dagger$ & Home $=$ centre \\
\hline SIP at 8 month follow-up & $2.83(14.5)$ & $3.40(11.1)$ & $0.61 \dagger$ & Home $=$ centre \\
\hline SIP at 14 month follow-up & $2.00(8.3)$ & $3.70(11.8)$ & $0.06 \dagger$ & Home $=$ centre \\
\hline \multicolumn{5}{|c|}{ Dalal et al, ${ }^{21} 2007$, Taylor et al, ${ }^{31} 2007$} \\
\hline \multicolumn{5}{|l|}{ At 9 month follow-up: } \\
\hline MacNew global score & $5.61(1.14)$ & $5.54(1.10)$ & 0.71 & Home $=$ centre \\
\hline EQ-5D & $0.74(0.04)$ & $0.78(0.04)$ & 0.57 & Home $=$ centre \\
\hline \multicolumn{5}{|l|}{ Jolly et al, ${ }^{22} 2007$} \\
\hline \multicolumn{5}{|l|}{ At 6 month follow-up: } \\
\hline EQ-5D & $0.74(0.26)$ & $0.76(0.23)$ & 0.37 & Home $=$ centre \\
\hline \multicolumn{5}{|l|}{ SF-12 } \\
\hline PCS & $42.28(10.9)$ & $42.56(10.8)$ & 0.8 & Home $=$ centre \\
\hline MCS & $49.19(10.1)$ & $50.33(9.6)$ & 0.3 & Home $=$ centre \\
\hline EQ-5D at 12 month follow-up & $0.74(0.27)$ & $0.76(0.23)$ & $0.52 \dagger$ & Home $=$ centre \\
\hline EQ-5D at 24 month follow-up & $0.73(0.29)$ & $0.75(0.26)$ & $0.39 \dagger$ & Home $=$ centre \\
\hline \multicolumn{5}{|c|}{$\begin{array}{l}\text { MCS=mental component score; } P C S=\text { physical component score; } S F-12=\text { short form } 12 \text { item survey; SF-36=short } \\
\text { form } 36 \text { item survey; SIP=sickness impact profile. } \\
\text { *Home = centre: no significant difference }(P>0.05) \text { in HRQoL (health related quality of life) between home and } \\
\text { centre based groups at follow-up; home }>\text { centre: significant }(P \leq 0.05) \text { higher HRQoL in home } v \text { centre based } \\
\text { groups at follow-up; home < centre: significant }(P \leq 0.05) \text { lower HRQoL in home } v \text { centre based groups at follow- } \\
\text { up. } \\
\text { tCalculated by authors of this report based on independent two group } t \text { test. }\end{array}$} \\
\hline
\end{tabular}

readmission to hospital). Healthcare costs seem to depend on the healthcare economy in which cardiac rehabilitation is provided; however, we found no consistent evidence to support an important difference in the healthcare costs associated with home based and centre based programmes. Evidence supported superior adherence and completion of rehabilitation by home based users. This is further supported by a recently published audit from one centre in Cornwall, which reported better adherence for home based rehabilitation (87\%) than hospital based classes (49\%). ${ }^{19}$

Our findings are consistent with a recent systematic review by Jolly et al,${ }^{20}$ though our review substantially increases the body of evidence that compares home based and centre based cardiac rehabilitation. We identified 12 randomised controlled trials in 1938 patients with cardiac disease compared with the previous six trials in 749 patients. The review by Jolly et al was critical of the variety of home based cardiac rehabilitation interventions and the small size and poor quality of trials. ${ }^{20}$ Since publication of that review ${ }^{20}$ data from two relatively large and high quality randomised controlled trials (funded by the NHS) in the UK have been published. ${ }^{212231}$ The model of home based provision in the largest three of the included trials ${ }^{212230}$ was the "Heart Manual"-a home based cardiac rehabilitation programme that consists of a self help manual supported by a facilitator (fig 12). ${ }^{38}$ This is the only validated home based programme that is recommended by the National Institute for Health and Clinical Excellence in the UK as an alternative to centre based programmes for patients after myocardial infarction. ${ }^{8}$

The mainstay approach to delivery of cardiac rehabilitation in many countries involves inpatient and outpatient hospital based provision. In North America, cardiac rehabilitation often takes place in a supervised university or community setting. The availability of home based programmes provides an opportunity to widen access to and participation in cardiac rehabilitation and thereby to improve uptake and adherence. Furthermore, home based cardiac rehabilitation might be a less costly alternative for healthcare economies than the more traditional hospital based approach. Data from the UK, however, suggest that only about $20 \%$ of cardiac rehabilitation programmes

\section{Centre based CR Home based CR}

$\begin{array}{lcc}\text { Bell } 1998^{30} & 15 / 68 & 8 / 70 \\ \text { Dalal } 2007^{21} & 10 / 44 & 15 / 60 \\ {\text { Gordon } 2002 \text { (community) }^{26}}^{26} & 1 / 26 & 6 / 49 \\ \text { Gordon } 2002 \text { (supervised) }^{26} & 1 / 26 & 4 / 54 \\ \text { Jolly } 2007^{22} & 45 / 262 & 49 / 263 \\ \text { Total }(95 \% \mathrm{Cl} \text { ) } & 72 / 426 & 82 / 496 \\ \text { Test for heterogeneity: } \chi^{2}=4.48, \mathrm{df}=4, \mathrm{P}=0.34, \mathrm{I}^{2}=11 \% \\ \text { Test for overall effect: } \mathrm{z}=0.16, \mathrm{P}=0.88\end{array}$

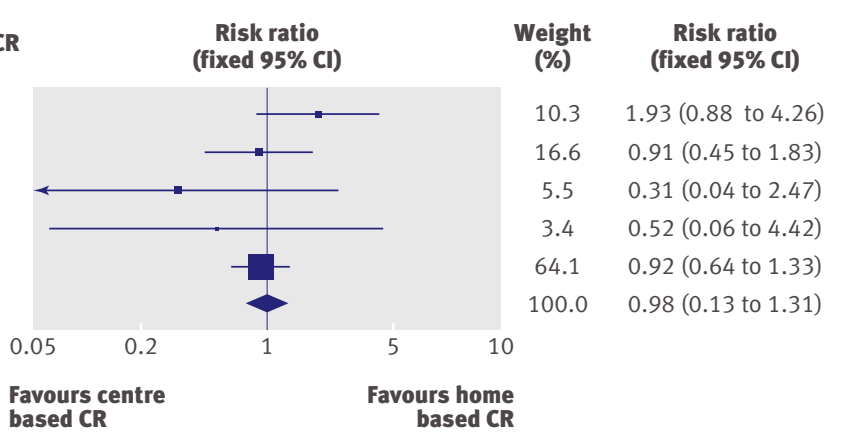


Table 7|Summary of adherence at follow-up in home and centre based settings with method for or definition of assessment of adherence*

\begin{tabular}{|c|c|c|c|c|}
\hline & \multicolumn{3}{|c|}{ Findings } & \multirow{2}{*}{$\begin{array}{l}\text { Difference between } \\
\text { groups } \dagger\end{array}$} \\
\hline & Home & Centre & $P$ value & \\
\hline \multicolumn{5}{|l|}{ Miller et al, ${ }^{27} 1984$, DeBusk et al, ${ }^{28} 1985$, Taylor et al, ${ }^{29} 1986$ : } \\
\hline Ratio (\%) of exercise session completed $v$ prescribed at 6 months & $50: 70(72)$ & $28: 40(71)$ & NA & Home $=$ centre $\ddagger$ \\
\hline \multicolumn{5}{|l|}{ Sparks et al, ${ }^{37} 1993:$} \\
\hline Sessions attended (\%) at 3 months & 93 & 88 & NA & Unclear \\
\hline \multicolumn{5}{|l|}{ Carlson et al, ${ }^{32} 2000$ : } \\
\hline No (\%) of patients who attended all three classes on nutrition and risk factors at 6 months & $27 / 38(71)$ & $33 / 42(79)$ & $0.438 \S$ & Home $=$ centre \\
\hline Total exercise over follow-up (No (SD) of sessions $\geq 30$ minutes) at 6 months & $111.8(29.1)$ & $98.1(33.4)$ & $0.06 \pi$ & Home $=$ centre \\
\hline \multicolumn{5}{|l|}{ Gordon et al, ${ }^{26} 2002$} \\
\hline $\begin{array}{l}\text { Completed scheduled appointments (exercise sessions, office/on site visits, } \\
\text { "telephone visits" in accordance with intervention protocol) (\%) at } 3 \text { months }\end{array}$ & $\begin{array}{l}83 \text { supervised by doctor; } \\
86 \text { community based }\end{array}$ & 81 & - & Home $=$ centre $\ddagger$ \\
\hline \multicolumn{5}{|l|}{ Arthur et $\mathrm{al}^{36}{ }^{36} 2002$, Smith et $\mathrm{al}^{33}{ }^{33} 2004$ : } \\
\hline Mean (SD) No of exercise session reported/week at 6 months & $6.5(4.6)$ & $3.7(2.6)$ & $0.0001 \rrbracket$ & Home > centre \\
\hline Patients seeking dietician consultation (\%) (No (SD) of visits) at 6 months & $50(3.5(2.5))$ & $53(3.6(2.3))$ & - & Unclear \\
\hline Patients seeking psychologist consultation (\%) (No (SD) of visits) at 18 months & $42(2.6(2.4))$ & $51(2.5(2.2))$ & - & Home $=$ centre $\ddagger$ \\
\hline Mean (SD) level of physical activity (PASE) at 18 months & $232.6(99.4)$ & $170.0(89.2)$ & $0.0001 \rrbracket$ & Home > centre \\
\hline \multicolumn{5}{|l|}{ Marchionni et al, $^{24} 2003$ : } \\
\hline No (SD) of exercise sessions completed at 4 months & $37.3(3.4)$ & $34.3(4.4)$ & $<0.0001 \rrbracket$ & Home > centre \\
\hline \multicolumn{5}{|l|}{ Daskapan et al, ${ }^{34} 2005:$} \\
\hline Percentage of sessions attended at 3 months & 97 & 81 & NA & Unclear \\
\hline \multicolumn{5}{|l|}{ Dalal et al, $^{21} 2007:$} \\
\hline No (\%) who participated in intervention at 9 months & $40 / 60(67)$ & $32 / 44(72)$ & $0.51 \S$ & Home $=$ centre \\
\hline \multicolumn{5}{|l|}{ Jolly et al, ${ }^{22} 2007:$} \\
\hline \multicolumn{5}{|l|}{ Hours (SD) of self reported activity weighted for intensity at: } \\
\hline 3 months & $23.2(22.1)$ & $18.7(19.3)$ & $0.06 \pi$ & Home $=$ centre \\
\hline 6 months & $16.4(17.0)$ & $18.1(25.4)$ & $0.4 \pi$ & Home $=$ centre \\
\hline 12 months & $19.2(20.8)$ & $15.9(16.7)$ & $0.06 \pi$ & Home $=$ centre \\
\hline 24 months & $18.9(18.4)$ & $16.6(16.4)$ & $0.16 \pi$ & Home $=$ centre \\
\hline
\end{tabular}

$\mathrm{NA}=$ not available; could not be calculated.

*Not reported for Bell et al, ${ }^{30} 1998$, Kassaian et al, ${ }^{25} 1998$, and Wu et al, ${ }^{35} 2008$.

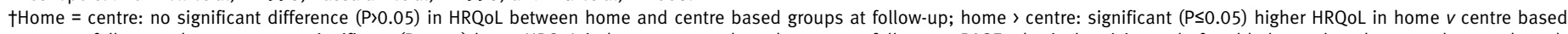

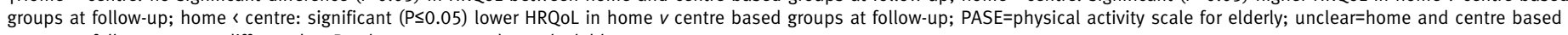
groups at follow-up seem different but $P$ value not reported or calculable.

¥Home and centre based groups at follow-up seem to be similar but $P$ value not reported or calculable.

$\S$ Calculated by authors of this report based on $x^{2}$ test.

ॠCalculated by authors of this report based on independent $t$ test.

currently offer an evidence based, home based option (English Cardiac Network survey 2008, Jane Flint, personal communication).

Our review has limitations. The recruitment of the included trials was largely limited to patients with stable coronary heart disease after acute myocardial infarction or revascularisation, with few patients with heart failure included. Although most patients in this review were exposed to the Heart Manual model of home based cardiac rehabilitation, evidence showed considerable statistical heterogeneity for several outcomes across the trials. This heterogeneity reflects the variety of centre based cardiac rehabilitation interventions, differences in recruitment and characteristics of patients, and variation in some outcome assessments (such as exercise capacity) across studies. Nevertheless, it is reassuring that our findings were generally consistent across various sensitivity analyses undertaken to
Centre based CR Home based CR

$\begin{array}{lcc}\text { Bell } 1998^{30} & 12 / 152 & 7 / 99 \\ \text { Dalal } 2007^{21} & 4 / 60 & 1 / 44 \\ \text { Daskapan } 2005^{34} & 1 / 15 & 0 / 14 \\ \text { Jolly } 2007^{22} & 3 / 263 & 3 / 262 \\ \text { Total }(95 \% \mathrm{Cl}) & 20 / 490 & 11 / 419 \\ \text { Test for heterogeneity: } \chi^{2}=1.00, \mathrm{df}=3, \mathrm{P}=0.80, \mathrm{I}^{2}=0 \%\end{array}$

Test for heterogeneity: $\chi^{2}=1.00, \mathrm{df}=3, \mathrm{P}=0.80, \mathrm{I}^{2}=0 \%$

Test for overall effect: $z=0.76, P=0.45$

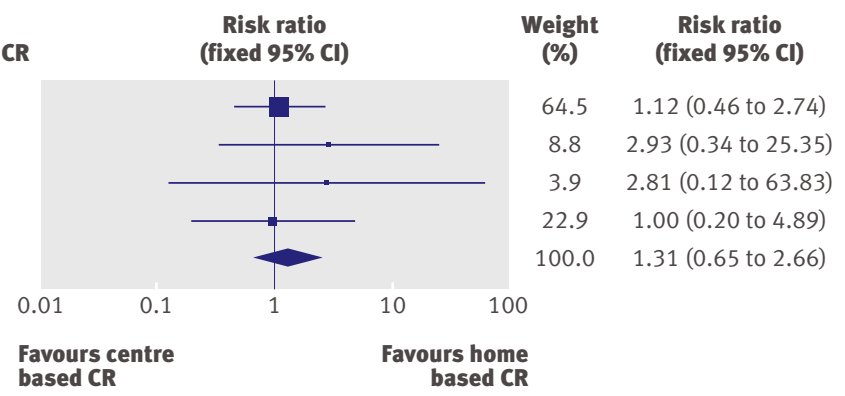


Table 8|Summary of costs in home and centre based settings. Figures are means (SD or $95 \%$ confidence interval)

\begin{tabular}{|c|c|c|c|c|}
\hline Variable & $\begin{array}{l}\text { Carlson } \\
\text { et al,32 } 2000\end{array}$ & $\begin{array}{l}\text { Marchionni } \\
\text { et al,24 } 2003\end{array}$ & $\begin{array}{l}\text { Dalal et al,21 2007; } \\
\text { Taylor et al,312007 }\end{array}$ & Jolly et al,22 2007 \\
\hline Follow-up (months) & 6 & 14 & 9 & 24 \\
\hline Year of costs & NR & 2000 & $2002-3$ & 2003 \\
\hline \multicolumn{5}{|c|}{ Mean cost of cardiac rehabilitation programme (per patient): } \\
\hline Home & $\$ 1519$ & $\$ 1650$ & $£ 170(8)$ & $£ 198$ (189 to 209) \\
\hline Hospital & $\$ 2349$ & $\$ 8841$ & $£ 200(3)$ & $£ 157$ (139 to 175$)$ \\
\hline Mean $(95 \% \mathrm{Cl})$ difference & - & - & $£ 30(-45$ to -12$)$ & - \\
\hline$P$ value & - & - & 0.001 & 0.05 \\
\hline Costs considered & $\begin{array}{l}\text { Staff, ECG, } \\
\text { monitoring }\end{array}$ & NR & Staff, exercise equipment, staff travel & Staff, telephone consultations, staff travel \\
\hline \multicolumn{5}{|l|}{ Mean total healthcare costs (per patient): } \\
\hline Home & NR & $\$ 21298$ & $£ 3279$ (374) & NR \\
\hline Hospital & NR & $\$ 13246$ & $£ 3201$ (443) & NR \\
\hline Mean $(95 \% \mathrm{Cl})$ difference & - & - & $£ 78(-1103$ to 1191$)$ & - \\
\hline$P$ value & - & - & 0.894 & - \\
\hline Additional healthcare costs considered & - & NR & $\begin{array}{l}\text { Readmissions, revascularisations, secondary } \\
\text { preventive medication, investigations, primary } \\
\text { care consultations }\end{array}$ & - \\
\hline Comments & - & - & - & $\begin{array}{l}\text { With inclusion of patients' costs (travel and time), } \\
\text { societal costs of home and hospital cardiac } \\
\text { rehabilitation were not significantly different }\end{array}$ \\
\hline
\end{tabular}

explore this heterogeneity. Trials were pooled with a random effects model for meta-analysis in the presence of statistical heterogeneity. Most studies were of relatively short duration, with only one trial reporting outcomes at 24 months. $^{22}$

Patients' preference has been hypothesised to have an impact on uptake and adherence to home based cardiac rehabilitation, and evidence suggests that white patients who work full time or part time and feel they have limited time are more likely to have a preference for home based cardiac rehabilitation. ${ }^{39}$ Such a hypothesis is difficult to test in a traditional randomised controlled trial so our finding of similar adherence between home based and centre based approaches needs to be interpreted with caution. The trial by Dalal et al (Cornwall heart attack rehabilitation management study (CHARMS $)^{21}$ ) used a comprehensive cohort design, which incorporated an element of preference-by which patients could choose between home based and hospital based cardiac rehabilitation -in addition to the randomised element of home based and centre based allocation. The authors reported that all of the primary and secondary outcomes were similar between the home and hospital preference arms and the randomised comparison. Adherence to home based cardiac rehabilitation was also comparable between the randomised (75\%) and preference arms (73\%). This finding does not support

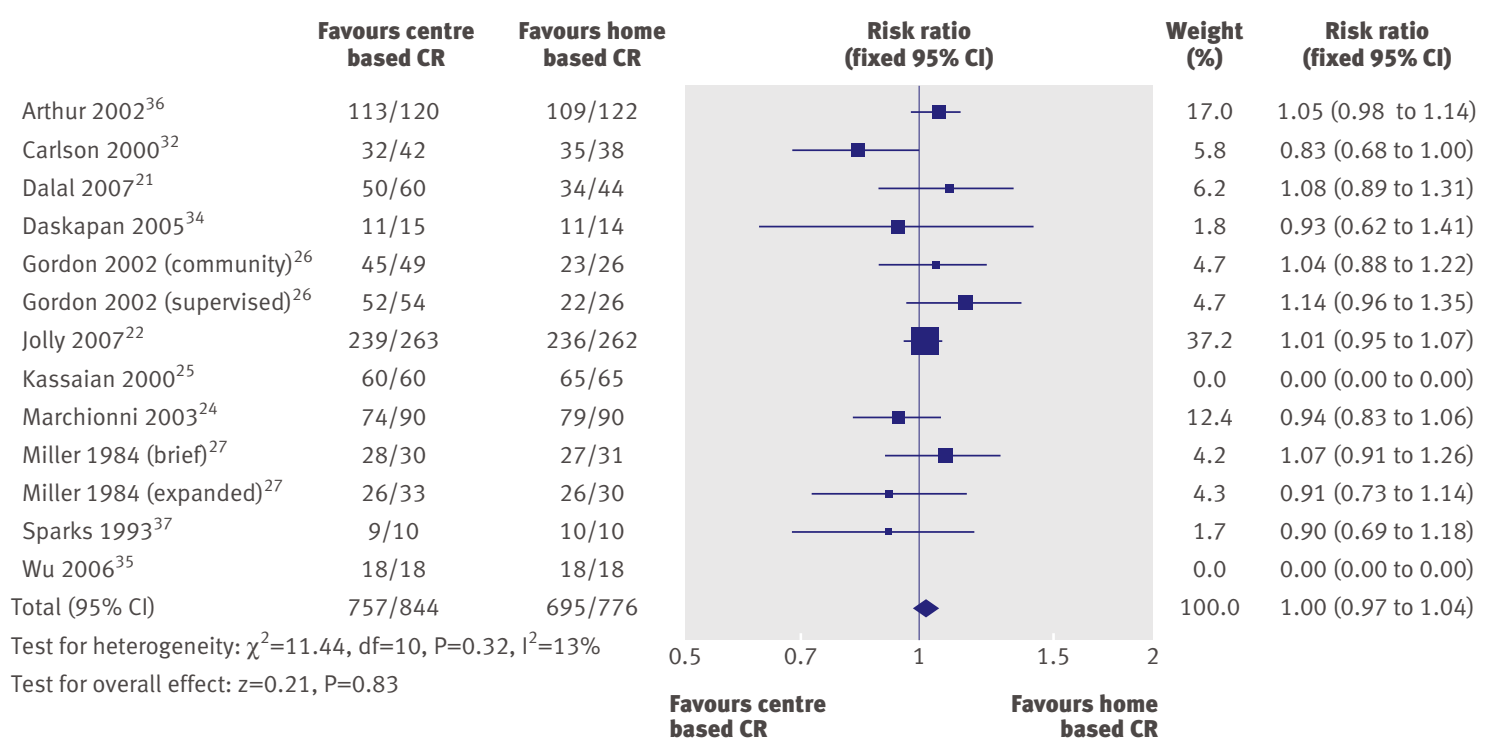

Fig 11 | Number of participants with outcome data at follow-up (completers) 
Table $9 \mid$ Summary of use of health care in home and centre based settings by months of follow-up

\begin{tabular}{|c|c|c|c|c|c|c|c|c|}
\hline \multirow[b]{2}{*}{ Variable } & \multirow{2}{*}{$\begin{array}{l}\text { Dalal et al,21 2007, } \\
\text { Taylor et al,31 } 2007 \\
\quad \text { ( } 9 \text { months) }\end{array}$} & \multirow[b]{2}{*}{$\begin{array}{c}\text { Gordon et al,26 } 2002 \\
\text { (3 months }\end{array}$} & \multicolumn{2}{|c|}{ Bell et al,30 1998} & \multirow[b]{2}{*}{$\begin{array}{l}\text { Carlson et al,32 } \\
2000 \text { (6 months }\end{array}$} & \multirow{2}{*}{$\begin{array}{c}\text { Marchionni et al,24 } \\
2003 \\
\text { (14 months) }\end{array}$} & \multicolumn{2}{|c|}{ Jolly et al,22 2007} \\
\hline & & & $0-6$ months & 6-12 months & & & 12 months & 24 months \\
\hline \multicolumn{9}{|c|}{ No (\%) of patients readmitted to hospital: } \\
\hline Time (months): & - & - & - & - & - & - & $6-12$ & $12-24$ \\
\hline Home & $9 / 60(15)$ & - & $21 / 90(23)$ & $13 / 89(15)$ & - & - & - & - \\
\hline Hospital & $6 / 44(14)$ & - & $19 / 88(22)$ & $12 / 84(14)$ & - & - & - & - \\
\hline$P$ value & 0.84 & - & $0.78^{\star}$ & $0.95^{\star}$ & - & - & - & - \\
\hline \multicolumn{9}{|c|}{ Mean (SD) No of readmissions: } \\
\hline Home & $2.2(0.9) \dagger$ & - & - & - & - & 0.46 (SE 0.1) & $0.08(0.34)$ & $0.20(0.45)$ \\
\hline Hospital & $1.2(0.6)$ & - & - & - & - & 0.33 (SE 0.1) & $0.12(0.41)$ & $0.26(0.57)$ \\
\hline Pvalue & 0.38 & - & - & - & - & $0.49^{*}$ & 0.3 & 0.3 \\
\hline \multicolumn{9}{|c|}{ Mean (SD) No of primary care consultations: } \\
\hline Time period (mo & ths): & & & & & & $9-12$ & $21-24$ \\
\hline Home & $6.3(0.6)$ & - & $6.6(3.6) \ddagger$ & $5.4(4.1)$ & - & - & $0.65(1.14)$ & $0.53(1.14)$ \\
\hline Hospital & $7.0(0.9)$ & - & $6.6(4.1)$ & $4.6(3.7)$ & - & - & - & $0.66(1.42)$ \\
\hline$P$ value & 0.514 & - & $1.00^{*}$ & $0.19^{*}$ & - & - & - & - \\
\hline \multicolumn{9}{|c|}{ No (\%) of patients taking secondary prevention medication: } \\
\hline \multicolumn{9}{|l|}{$\beta$ blockers: } \\
\hline Home & $31 / 49(63)$ & $36 / 97(37)$ & - & - & $19 / 38$ & - & $169(72.2)$ & $161(71.6)$ \\
\hline Hospital & $24 / 34(71)$ & $17 / 45(38)$ & - & - & $18 / 42$ & - & $171(73.4)$ & $164(72.2)$ \\
\hline$P$ value & 0.49 & NS & - & - & $0.52^{*}$ & - & 0.8 & 0.9 \\
\hline \multicolumn{9}{|l|}{ ACE inhibitors: } \\
\hline Home & $30 / 49(61)$ & $25 / 97(26) \S$ & - & - & $4 / 38$ & - & $176(75.2) \S$ & $177(78.7) \S$ \\
\hline Hospital & $24 / 33(73)$ & $8 / 45(18)$ & - & - & $4 / 42$ & - & $161(69.1) \S$ & $156(68.7) \S$ \\
\hline P value & 0.28 & NS & - & - & $0.88^{*}$ & - & 0.1 & 0.02 \\
\hline \multicolumn{9}{|c|}{ Antihypertensives: } \\
\hline Home & & $73 / 97(75)$ & - & - & $5 / 38$ & - & - & - \\
\hline Hospital & & $33 / 45(73)$ & - & - & $8 / 42$ & - & - & - \\
\hline$P$ value & & NS & - & - & $0.47^{\star}$ & - & - & - \\
\hline \multicolumn{9}{|l|}{ Statins } \\
\hline Home & 48/49 (98) & - & - & - & $15 / 38$ & - & $216(92.3)^{\star \star}$ & $195(86.7)^{\star \star}$ \\
\hline Hospital & $30 / 35(88)$ & - & - & - & $20 / 42$ & - & $221(94.8)^{\star \star}$ & $206(90.7)^{\star \star}$ \\
\hline$P$ value & $0.18^{*}$ & - & - & - & $0.54^{*}$ & - & 0.3 & 0.2 \\
\hline \multicolumn{9}{|l|}{ Antiplatelets: } \\
\hline Home & 46/49 (94) & 94/97 (97)ף & - & - & - & - & 227 (97.0)†† & 214 (95.1)†† \\
\hline Hospital & $30 / 35(86)$ & 45/45 (100)ף & - & - & - & - & $226(97.0) \dagger \dagger$ & 220 (96.9)†† \\
\hline$P$ value & 0.21 & NS* & - & - & - & - & 1.0 & 0.3 \\
\hline
\end{tabular}

NS=not significant.

*Calculated by authors of present report.

†Number of nights.

‡GP consultation.

§Angiotensin converting enzyme (ACE) inhibitor or angiotensin II receptor antagonist.

TAntiplatelets and anticoagulants.

${ }^{\star *}$ Cholesterol lowering drug.

††Aspirin or antiplatelet drug.

the hypothesis that patients who can choose a programme to suit their lifestyle and preferences will have a higher rate of adherence and improved outcomes. Superior rates of adherence to home based rehabilitation, however, have been reported, ${ }^{19}$ and offering patients a choice of rehabilitation could improve the current low uptake, ${ }^{40}$ especially in older patients, the socially deprived, ethnic minorities, and those from rural areas who might have practical problems in accessing centre based facilities, in whom poor rates of uptake and adherence have been reported. ${ }^{41}$
Small differences in the costs of cardiac rehabilitation were seen for the two trials based in the UK. ${ }^{3142}$ The trial by Jolly et al (Birmingham rehabilitation uptake maximisation (BRUM)) found that the home based programme was more costly, possibly because of the higher rate of home visiting undertaken in this study compared with CHARMS. ${ }^{312}$ Relatively higher costs were reported with intensive, highly monitored cardiac rehabilitation programmes offered in North America and western Europe. ${ }^{2432}$ Current reimbursement tariffs in the US require medical supervision, but as only $10-20 \%$ of patients in the US receive cardiac 


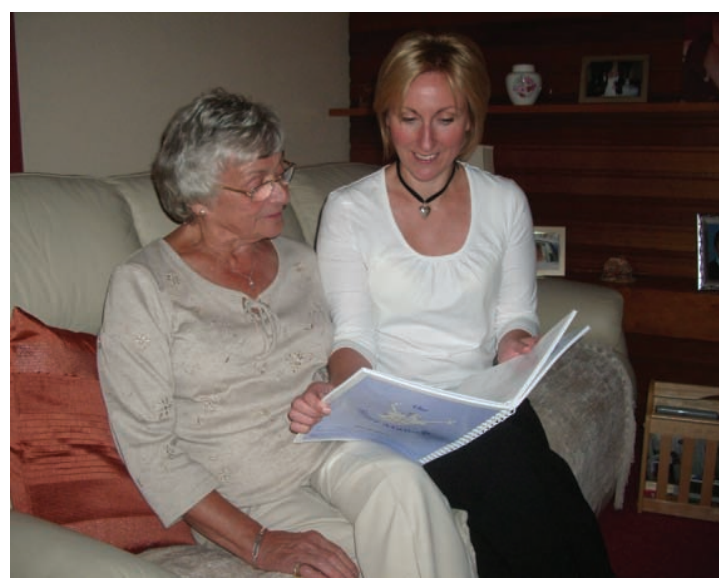

Fig 12 Home based cardiac rehabilitation

rehabilitation after myocardial infarction and coronary revascularisation, there is a case to be made for widening access. ${ }^{10}$

\section{Implications for practice}

Home based and hospital or centre based cardiac rehabilitation seem to be equally effective in improving clinical outcomes and health related quality of life outcomes in low risk patients after acute myocardial infarction and revascularisation. This finding, together with an absence of evidence of differences in healthcare costs between the two approaches, supports the further provision of evidence based, home based cardiac rehabilitation programmes such as the Heart Manual. The choice of participating in a more traditional supervised centre based or home based programme should reflect the preference of the individual patient.

\section{Implications for research}

Data are needed to determine whether the effects of home based and centre based cardiac rehabilitation reported in short term trials can be confirmed in the longer term. Comparative trials are needed to assess

\section{WHAT IS ALREADY KNOWN ON THIS TOPIC}

Less than $40 \%$ of people who survive a heart attack in the UK participate in a cardiac rehabilitation programme

Suboptimal participation is prevalent in many other countries including the US

Home based cardiac rehabilitation programmes have been introduced in North America and Europe in an attempt to improve uptake, especially for older people, socially deprived people, ethnic minorities, and those from rural areas who encounter difficulties in attending centre based facilities

\section{WHAT THIS STUDY ADDS}

Home based and centre based forms of cardiac rehabilitation are equally effective in improving clinical and health related quality of life outcomes in patients with a low risk of further events after myocardial infarction or revascularisation

Individual patients should be able to choose whether to participate in a more traditional supervised centre based or evidence based, home based programme such as the Heart Manual; this approach should improve the current low uptake of cardiac rehabilitation the relative impact of supervised centre based and home based cardiac rehabilitation in patients with heart failure. Such studies need to consider economic factors and patient related outcomes, including costs to the healthcare system and health related quality of life.

We thank Philippa Davies, who undertook selection of updated titles and abstracts from updated searches, and Sue Whiffen for her administrative assistance. The results of a Cochrane review can be interpreted differently, depending on people's perspectives and circumstances. Please consider the conclusions presented carefully. They are the opinions of review authors, and are not necessarily shared by The Cochrane Collaboration. This paper is based on a Cochrane review first published in The Cochrane Library 2010, Issue 1 (see www. thecochranelibrary.com/for information). Cochrane reviews are regularly updated as new evidence emerges and in response to feedback, and The Cochrane Library should be consulted for the most recent version of the review.

Contributors: RST, KJ, and TM were involved in the design of the review. TM developed the search strategy. Phillipa Davies and RST conducted the searches. AZ undertook study selection, data extraction, assessment of risk of bias, and data analysis. AZ and RST wrote the first draft of the review with $\mathrm{HD}$, and all authors contributed to the various drafts of the report. HD and RST are guarantors.

Funding: The study was funded by the National Institute for Health Research Cochrane Heart Programme, UK, and the European Union unde transparency of the National Health System Drug Reimbursement Decisions, Poland. RST was also partly funded by South West Primary Care Trust.

Competing interests: KJ was the first author of the previous systematic review of home based versus centre based cardiac rehabilitation and principal investigator of the BRUM trial of home based versus centre based cardiac rehabilitation. HD was principal investigator on the CHARMS trial of home based versus centre based cardiac rehabilitation and was invited to become an honorary medical consultant to the Heart Manual programme after this paper was submitted for publication. RST was a coauthor of the previous systematic review of home based versus centre based cardiac rehabilitation and a coinvestigator of the BRUM and CHARMS trials of home based versus centre based cardiac rehabilitation. Ethical approval: Not required.

Data sharing: No additional data available.

1 Neal B. Secondary prevention of cardiovascular disease: fixed dose combinations. In: Kaplan W, Laing R, eds. Priority medicines for Europe and the world. World Health Organization, 2004.

2 Law MR, Watt HC, Wald NJ. The underlying risk of death after myocardial infarction in the absence of treatment. Arch Intern Med 2002;162:2405-10.

3 World Health Organization. The world health report: conquering suffering, enriching humanity. WHO, 1997.

4 Jolliffe JA, Rees K, Taylor RS, Thompson D, Oldridge N, Ebrahim S. Exercise-based rehabilitation for coronary heart disease. Cochrane Database Syst Rev 2001;1:CD001800.

5 Taylor RS, Brown A, Ebrahim S, Jolliffe J, Noorani H, Rees K, et al. Exercise-based rehabilitation for patients with coronary heart disease: systematic review and meta-analysis of randomized controlled trials. Am J Med 2004;116:682-92.

6 Balady GJ, Williams MA, Ades PA, Bittner V, Comoss P, Foody JM, et al. Core components of cardiac rehabilitation/secondary prevention programs: 2007 update: a scientific statement from the American Heart Association Exercise, Cardiac Rehabilitation, and Prevention Committee, the Council on Clinical Cardiology; the Councils on Cardiovascular Nursing, Epidemiology and Prevention, and Nutrition, Physical Activity, and Metabolism; and the American Association of Cardiovascular and Pulmonary Rehabilitation. Circulation 2007;115:2675-82.

7 Graham I, Atar D, Borch-Johnsen K, Boysen G, Burell G, Cifkova R, et al. European guidelines on cardiovascular disease prevention in clinical practice: full text. Fourth Joint Task Force of the European Society of Cardiology and other societies on cardiovascular disease prevention in clinical practice (constituted by representatives of nine societies and by invited experts). Eur J Cardiovasc Prev Rehabil 2007;14(suppl 2):1-113S.

8 National Institute for Health and Clinical Excellence.Secondary prevention in primary and secondary care for patients following a myocardial infarction. NICE, 2007. www.nice.org.uk/CG48.

9 Stone JA, Arthur HM. Canadian guidelines for cardiac rehabilitation and cardiovascular disease prevention, second edition, 2004: executive summary. Can J Cardiol 2005;21(suppl D):3-19S. 
10 Wenger NK. Current status of cardiac rehabilitation. J Am Coll Cardiol 2008;51:1619-31.

11 Ferguson EE. Cardiac rehabilitation-an effective and comprehensive but underutilized program to reduce cardiovascular risk in patients with CVD. US Cardiovascular Disease 2006. www.touchcardiology.com/articles/cardiac-rehabilitation-aneffective-and-comprehensive-underutilized-program-reducecardiova.

12 Ades P, Waldmann M, McCann W, Weaver S. Predictors of cardiac rehabilitation participation in older coronary patients. Arch Intern Med 1992;152:1033-5.

13 Andrew GM, Oldridge NB, Parker JO, Cunningham DA, Rechnitzer PA Jones NL, et al. Reasons for dropout from exercise programs in postcoronary patients. Med Sci Sports Exerc 1981;13:164-8.

14 Campbell N, Grimshaw J, Rawles J, Ritchie L. Cardiac rehabilitation: the agenda set by post-myocardial infarction patients. Health Educ) 1994:53:409-20.

15 Pell J, Pell A, Morrison C, Blatchford O, Dargie H. Retrospective study of influence of deprivation on uptake of cardiac rehabilitation. BMJ 1996;313:267-8.

16 Nohara R, Kambara H, Hohiuddin IH, Ono S, Okuda K, Makita S, et al. Cardiac sports rehabilitation for patients with ischaemic heart disease. Jpn Circ J 1990;54:1443-50.

17 Evenson K, Fleury J. Barriers to outpatient cardiac rehabilitation participation and adherence. J Cardiopulm Rehabil 2000;20:241-6.

18 Cannistra LB, Balady GJ, O’Malley C), Weinger DA, Ryan TJ. Comparison of the clinical profile and outcome of women and men in cardiac rehabilitation. Am J Cardiol 1992;69:1274-9.

19 Dalal HM, Evans PH. Achieving national service framework standards for cardiac rehabilitation and secondary prevention. BMJ 2003;326:481-4.

20 Jolly K, Taylor RS, Lip GY, Stevens A. Home-based cardiac rehabilitation compared with centre-based rehabilitation and usual care: a systematic review and meta-analysis. Int J Cardiol 2006;111:343-51.

21 Dalal HM, Evans PH, Campbell JL, Taylor RS, Watt A, Read KL, et al. Home-based versus hospital-based rehabilitation after myocardial infarction: a randomized trial with preference arms-Cornwall heart attack rehabilitation management study (CHARMS). Int J Cardiol 2007;119:202-11.

22 Jolly K, Taylor R, Lip GY, Greenfield S, Raftery J, Mant I, et al. The Birmingham rehabilitation uptake maximisation study (BRUM). Home-based compared with hospital-based cardiac rehabilitation in a multi-ethnic population: cost-effectiveness and patient adherence. Health Technol Assess 2007;11:1-118.

23 Higgins JPT, Green S, eds. Cochrane handbook for systematic reviews of interventions: version 5.0.1. Cochrane Collaboration, 2008.

24 Marchionni N, Fattirolli F, Fumagalli S, Oldridge N, Del Lungo F, Morosi L, et al. Improved exercise tolerance and quality of life with cardiac rehabilitation of older patients after myocardial infarction: results of a randomized, controlled trial. Circulation 2003;107:2201-6.

25 Kassaian M, Maleki M, Noohi F, Eftekharzadeh M, Arya A, Roshanali F, et al. Comparing effects of supervised versus homebased cardiac rehabilitation. Iranian Heart / 2000;1:95-102.

26 Gordon NF, English CD, Contractor AS, Salmon RD, Leighton RF, Franklin BA, et al. Effectiveness of three models for comprehensive cardiovascular disease risk reduction. Am J Cardiol 2002;89:1263-8.
27 Miller NH, Haskell WL, Berra K, DeBusk RF. Home versus group exercise training for increasing functional capacity after myocardial infarction. Circulation 1984;70:645-9.

28 DeBusk RF, Haskell WL, Miller NH, Berra K, Taylor CB, Berger WE III, et al. Medically directed at-home rehabilitation soon after clinically uncomplicated acute myocardial infarction: a new model for patient care. Am J Cardiol 1985;55:251-7.

29 Taylor CB, Houston-Miller N, Ahn DK, Haskell W, DeBusk RF. The effects of exercise training programs on psychosocial improvement in uncomplicated postmyocardial infarction patients. J Psychosom Res 1986;30:581-7.

30 Bell JM. A comparison of a multi-disciplinary home based cardiac rehabilitation programme with comprehensive conventional rehabilitation in post-myocardial infarction patients [PhD thesis]. University of London, 1998.

31 Taylor RS, Watt A, Dalal HM, Evans PH, Campbell JL, Read KL, et al. Home-based cardiac rehabilitation versus hospital-based rehabilitation: a cost effectiveness analysis. Int J Cardiol 2007;119:196-201.

32 Carlson JJ, Johnson JA, Franklin BA, VanderLaan RL. Program participation, exercise adherence, cardiovascular outcomes, and program cost of traditional versus modified cardiac rehabilitation. Am J Cardiol 2000;86:17-23.

33 Smith KM, Arthur HM, McKelvie RS, Kodis J. Differences in sustainability of exercise and health-related quality of life outcomes following home or hospital-based cardiac rehabilitation. Eur J Cardiovasc Prev Rehabil 2004;11:313-9.

34 Arthur HM, Smith KM, Kodis J, McKelvie R. A controlled trial of hospital versus home-based exercise in cardiac patients. Med Sci Sports Exerc 2002;34:1544-50.

35 Daskapan A, Arikan H, Caglar N, Tunali N, Ataman S. Comparison of supervised exercise training and home based exercise training in chronic heart failure. Saudi Med J 2005;26:842-7.

36 Wu SK, Lin YW, Chen CL, Tsai SW. Cardiac rehabilitation versus home exercise after coronary artery bypass graft surgery: a comparison of heart rate recovery. Am J Phys Med Rehabil 2006;85:711-7.

37 Sparks KE, Shaw DK, Eddy D, Hanigosky P, Vantrese J. Alternatives for cardiac rehabilitation patients unable to return to a hospital-based program. Heart Lung 1993;22:298-303.

38 Lewin B. Effects of self-help post-myocardial-infarction rehabilitation on psychological adjustment and use of health services. Lancet 1992;339:1036-40.

39 Grace S, McDonald J, Fishman D, Caruso V. Patient preferences for home-based versus hospital-based cardiac rehabilitation.J Cardiopulm Rehabil 2005;25:24-9.

40 Wingham J, Dalal HM, Sweeney KG, Evans PH. Listening to patients: choice in cardiac rehabilitation. Eur J Cardiovasc Nurs 2006;5:289-94.

41 Beswick AD, Rees K, Griebsch I, Taylor FC, Burke M, West RR, et al. Provision, uptake and cost of cardiac rehabilitation programmes: improving services to under-represented groups. Health Technol Assess 2004;8:iii-iv,ix-x,1-152.

42 Jolly K, Lip GY, Taylor RS, Raftery J, Mant J, Lane D, et al. The Birmingham rehabilitation uptake maximisation study (BRUM): a randomised controlled trial comparing home-based with centrebased cardiac rehabilitation. Heart 2009;95:36-42.

Accepted: 22 October 2009 